\title{
Assessing Residential Exposure Risk from Spills of Flowback Water from Marcellus Shale Hydraulic Fracturing Activity
}

\author{
Noura Abualfaraj *, Patrick L. Gurian ${ }^{(1)}$ and Mira S. Olson \\ CAEE Department, College of Engineering, Drexel University, 3141 Chestnut St., Philadelphia, PA 19104, USA; \\ plg28@drexel.edu (P.L.G.); mso28@drexel.edu (M.S.O.) \\ * Correspondence: na489@drexel.edu; Tel.: +1-267-474-0804
}

Received: 1 March 2018; Accepted: 3 April 2018; Published: 11 April 2018

\begin{abstract}
Identifying sources of concern and risk from shale gas development, particularly from the hydraulic fracturing process, is an important step in better understanding sources of uncertainty within the industry. In this study, a risk assessment of residential exposure pathways to contaminated drinking water is carried out. In this model, it is assumed that a drinking water source is contaminated by a spill of flowback water; probability distributions of spill size and constituent concentrations are fit to historical datasets and Monte Carlo simulation was used to calculate a distribution of risk values for two scenarios: (1) use of a contaminated reservoir for residential drinking water supply and (2) swimming in a contaminated pond. The swimming scenario did not produce risks of concern from a single exposure of $1 \mathrm{~h}$ duration, but 11 such 1-h exposures did produce risks of $10^{-6}$ due to radionuclide exposure. The drinking water scenario over a 30-year exposure duration produced cancer risk values exceeding $10^{-6}$ for arsenic, benzene, benzo(a)pyrene, heptachlor, heptachlor epoxide, pentachlorophenol, and vinyl chloride. However, this extended exposure duration is probably not realistic for exposure by a spill event. Radionuclides produced risks in the residential drinking water scenario of $10^{-6}$ in just $8 \mathrm{~h}$, a much more realistic timeline for continual exposure due to a spill event. In general, for contaminants for which inhalation exposure was applicable, this pathway produced the highest risks with exposure from ingestion posing the next greatest risk to human health followed by dermal absorption (or body emersion for radionuclides). Considering non-carcinogenic effects, only barium and thallium exceed target limits, where the ingestion pathway seems to be of greater concern than dermal exposure. Exposure to radionuclides in flowback water, particularly through the inhalation route, poses a greater threat to human health than other contaminants examined in this assessment and should be the focus of risk assessment and risk mitigation efforts.
\end{abstract}

Keywords: shale gas; hydraulic fracturing; flowback; risk assessment; drinking water

\section{Introduction}

The increase in the development and production of natural gas over the past two decades in the United States has been an ongoing source of environmental concern [1,2]. Technological advances in drilling techniques have made natural gas extraction from tight, impervious shale formations economically feasible. Shale gas extraction (typically referred to as unconventional drilling) combines directional drilling, which steers the drill bit horizontally along the shale formation allowing each well to access a larger area of rock, and hydraulic fracturing, the process of injecting pressurized water mixed with a proppant (typically sand) and chemical additives in order to create fractures within the rock through which gas can escape. The additives used in hydraulic fracturing fluid make up roughly 
$0.5-2 \%$ of the fluid and act as reducers and surfactants, while the proppant $(10-20 \%$ of the fracturing fluid) acts to prop open the fractures created in the shale allowing gas to flow to the well [3-8].

Sources of environmental and human health concerns from the shale gas industry include: stress on fresh water resources due to the large amount of water (2-5 million gallons) required for each fracturing process $[3,4,7,9,10]$, air quality effects from the release of gas, volatile organic compounds (VOCs), and particulate matter into the atmosphere [1,11-16], and water quality effects from surface spills or failures in the subsurface $[5,9,17-26]$. Shale gas development is of particular concern in the state of Pennsylvania, as it is currently the US' second producer of natural gas following Texas, and because the Marcellus shale, which underlies two-thirds of the state, is one of the largest natural gas reservoirs in the country $[22,27,28]$.

Research on the potential mechanisms for drinking water contamination from unconventional drilling, such as accidental spills, inadequate treatment, and improper disposal of waste water, has produced varied results. Some studies $[19,21,24]$ have found evidence of higher levels of thermogenic methane from shale in drinking water wells in closer proximity to unconventional wells. These studies have been criticized for having small sample sizes and for a lack of baseline data collected prior to drilling. Thermogenic methane geochemically consistent with Middle Devonian gases has been reportedly observed in streams in northern Pennsylvania [29]. One study [30] found no statistically significant relationship between methane concentration in drinking water and proximity to wells when examining pre- and post-drilling data provided by Chesapeake Energy Corporation, while another [31] suggests that the thermogenic gas present in drinking water may have originated from shale layers above the Marcellus shale and is, therefore, not an indicator of pollution caused by hydraulic fracturing.

Certain chemicals in hydraulic fracturing fluid and flowback water have the potential to cause severe adverse health effects after chronic or even acute exposure [1,32]. Studies have found that hydraulic fracturing wastewater generally has very high concentrations of salts and total dissolved solids, as well as levels of radionuclides, metals, and organic compounds that could be harmful to human health [32-38].

The US Environmental Protection Agency's (EPA) hydraulic fracturing risk assessment report released in 2016 concluded that the industry did not pose a systemic threat to drinking water quality, noting that incidents of failure were relatively rare when considering the total number of wells drilled across the United States [39]. On the other hand, studies of violation and compliance rates for natural gas wells in the state of Pennsylvania have found statistically significant higher rates of environmental violations related to cementing and casing failures, spills, and erosion and sediment control for unconventional wells over conventional wells [40-42].

An evaluation of a ground water contamination incident in Bradford County, Pennsylvania (PA) attributed to shale gas development found evidence of dissolved hydrocarbons and inorganics that potentially migrated from nearby wells with inadequate casings and annular pressure measurements exceeding allowable limits [43]. BTEX (benzene, toluene, ethylbenzene, and xylenes) measurements exceeded drinking water standards in groundwater near several spill incidents in Weld County, Colorado (CO), indicating a plausible route for groundwater contamination from hydraulic fracturing activity [44]. Elicitations of expert opinions in the oil and gas industry have shown that the exposure pathways of most concern regarding impacts on drinking water quality and human health are from accidental releases of flowback water or hydraulic fracturing fluid $[45,46]$.

While evidence of systemic negative impacts from shale gas extraction is limited, the literature highlights a degree of uncertainty associated with the shale gas industry, providing a reasonable motivation for examining its potential risk to human health. The goal of this study is to conduct a risk assessment for residential exposure of the general public to a set of carcinogenic and non-carcinogenic chemicals of concern to human health found in flowback water through several ingestion, inhalation, and dermal exposure pathway scenarios in order to better understand potential hazards and provide decision makers with tools to better inform safety practices and failure prevention. Given the amount 
of uncertainty associated with clean-up and remediation timelines regarding accidental or improper spills, this study utilizes long- and short-term exposure scenarios along with flowback water spill rates, volumes, and contaminant concentrations to develop remedial goals based on long-term Superfund exposure guidelines while also determining appropriate short-term exposure timelines to avoid human health impacts from high priority contaminants with adverse health effects.

\section{Materials and Methods}

The assessment presented in this paper is carried out following the EPA's recommended Superfund risk assessment guidelines for two residential exposure scenarios: (1) exposure through ingestion, inhalation, and dermal exposure to residential tap water contaminated with flowback water and (2) exposure through swimming in a pond contaminated with flowback water. Details and assumptions for each exposure scenario and pathway are described in this section.

\subsection{Residential Tap Water Exposure Scenario}

The exposure scenario examined in this analysis is modeled as a result of flowback water being accidentally spilled or improperly disposed of directly into a fresh water reservoir that is then used as a source of residential drinking water. The reservoir was assumed to have a volume of 44,000,000 $\mathrm{L}$ based on values used in Galada et al. [47], which adopted the EPA scenarios for contamination of rural water supplies by land application of biosolids [48]. The reservoir volume is used to dilute concentrations found in flowback water, assuming that it becomes completely mixed as it enters the fresh water source as described by Equation (1).

$$
C_{w}=\left(C_{\text {flowback }} \times V_{\text {flowback }}\right) / V_{\text {pond }}
$$

where,

$C_{w}=$ Chemical concentration in residential drinking water $(\mathrm{mg} / \mathrm{L})$

$C_{\text {flowback }}=$ Chemical concentration in flowback water $(\mathrm{mg} / \mathrm{L})$

$V_{\text {flowback }}=$ Volume of flowback water spilled (L)

$V_{\text {pond }}=$ Volume of drinking water reservoir/holding pond (L)

The contaminant concentration in drinking water is used to estimate exposure dose. In addition to the contaminant concentration, it is necessary to define the exposure duration and frequency parameters in order to determine the daily intake of each contaminant. In this assessment, it is assumed that an adult of average weight will be exposed to drinking water from the scenario described by Equation (1). Residential exposure to this contaminated drinking water source is examined through the following pathways:

1. Ingestion of contaminated drinking water: This scenario assumes direct ingestion of unfiltered residential drinking water. An average daily water ingestion rate of $2.5 \mathrm{~L} /$ day was used in this calculation [49].

2. Inhalation of VOCs that may volatilize from the water to the air: This exposure pathway applies to chemicals with a Henry's Law constant greater than $1 \times 10^{-5} \mathrm{~atm} \cdot \mathrm{m}^{3} / \mathrm{mole}$ and a molecular weight less than $200 \mathrm{~g} /$ mole, as they are most likely to volatilize from water during use and contaminate the air. Three carcinogens examined in this assessment meet these criteria, benzene, 1,2-dichloroethane, and vinyl chloride, as well as the radionuclides which may volatilize or aerosolize. This scenario assumes a default volatilization rate of $0.0005 \times 1000 \mathrm{~L} / \mathrm{m}^{3}$ based on an equation defining the relationship between a volatile chemical's concentration in water and its average volatilized concentration in the air [50]. This includes all household uses of water (showering/bathing, dish washing, cooking, etc.), and assumes an average daily air inhalation rate of $15 \mathrm{~m}^{3}$ /day [49]. 
3. Dermal exposure to contaminated water: This pathway examines direct skin contact with contaminated water during showering or bathing. This scenario assumes total skin surface area exposure for $43 \mathrm{~min}$ every day based on average values recommended by the Exposure Factors Handbook [49].

Daily exposure was assumed for each pathway (Tables A1 and A2). As standards for chronic exposure are more conservative than acute exposure standards, a chronic exposure was assumed [49]. Values, definitions, and data sources for all the variables required to estimate daily intake can be found in Appendix A (Tables A1 and A2). From there, exposure durations of concern for each exposure pathway are estimated by determining the exposure duration required for the maximum possible total risk to remain below target values (Total Cancer Risk $<10^{-6}$ for carcinogens, and Hazard Index $<1.0$ for non-carcinogens).

\subsection{Residential Swimming Exposure Scenario}

Similarly to the tap-water scenario, this exposure scenario is modeled as a result of flowback water being accidentally spilled or improperly disposed of directly into 44,000,000 $\mathrm{L}$ of fresh water. The pond volume is used to dilute concentrations found in flowback water, assuming that it becomes completely mixed as it enters the fresh water source as described by Equation (1). The exposed individual is then assumed to swim in the pond once for $1 \mathrm{~h}$. In this assessment, the following exposure pathways are considered: dermal exposure to contaminated pond water, accidental ingestion of contaminated pond water during swimming, and inhalation of volatiles in the contaminated pond water during swimming. For a single event, acute exposure parameters are assumed [49]. Exposure durations corresponding to target values of risk (cancer risk $<10^{-6}$ for carcinogens, and hazard index $<1.0$ for non-carcinogens) for each exposure pathway in this scenario are also estimated.

\subsection{Monte Carlo Simulation}

This study utilizes datasets on spill volumes and contaminant concentrations for wastewater generated from hydraulic fracturing activities typically categorized as either flowback or production water. Due to gaps in metadata associated with these datasets, it was not possible, in some cases, to distinguish between flowback and production water. For the purposes of this study, both will be referred to as 'flowback water'.

Flowback water sampling data from Abualfaraj et al. [33] were used in this analysis. This database reported the concentrations of constituents found in flowback water samples collected from 92 wells in the Marcellus shale region between March 2008 and December 2010. This study [33] prioritized parameters in this dataset based on their concentrations relative to drinking water standards, where high priority was given to constituents with concentrations that exceeded drinking water standards. Potential health effects of ingestion, inhalation, or dermal exposure to contaminants found in flowback water are shown in Table 1.

Table 1. Health effects from ingestion, dermal, and inhalation exposure to high priority contaminants in flowback water [51-53].

\begin{tabular}{clll}
\hline Contaminants & \multicolumn{1}{c}{ Ingestion } & \multicolumn{1}{c}{ Dermal } & \multicolumn{1}{c}{ Inhalation } \\
\hline Aluminum & $\begin{array}{l}\text { Neurobehavioral alterations; } \\
\text { skeletal effects (e.g., } \\
\text { osteomalacia) }\end{array}$ & $\begin{array}{l}\text { No known dermal health } \\
\text { effects }\end{array}$ & $\begin{array}{l}\text { Impaired lung function } \\
\text { and fibrosis }\end{array}$ \\
\hline Antimony & $\begin{array}{l}\text { Nausea, vomiting, diarrhea; } \\
\text { stomach cramps }\end{array}$ & Skin irritation & $\begin{array}{l}\text { Irritation to nose, throat, } \\
\text { mouth; cough; dizziness }\end{array}$ \\
\hline Arsenic * & $\begin{array}{l}\text { Gastrointestinal and } \\
\text { reproductive effects; possible } \\
\text { liver damage }\end{array}$ & $\begin{array}{l}\text { Dermatitis; } \\
\text { hyperpigmentation of } \\
\text { skin; potential } \\
\text { occupational carcinogen }\end{array}$ & $\begin{array}{l}\text { Respiratory distress in } \\
\text { animals }\end{array}$ \\
\hline Barium & $\begin{array}{l}\text { Gastroenteritis; muscle spasm; } \\
\text { slow pulse }\end{array}$ & $\begin{array}{l}\text { No known dermal health } \\
\text { effects }\end{array}$ & $\begin{array}{l}\text { Upper respiratory } \\
\text { system effects }\end{array}$ \\
\hline
\end{tabular}


Table 1. Cont.

\begin{tabular}{|c|c|c|c|}
\hline Contaminants & Ingestion & Dermal & Inhalation \\
\hline Benzene * & $\begin{array}{l}\text { Headache, nausea, staggered } \\
\text { gait; anorexia, weakness, } \\
\text { exhaustion }\end{array}$ & Skin irritation; dermatitis & $\begin{array}{l}\text { Respiratory system } \\
\text { effects; dizziness; } \\
\text { headache; associated } \\
\text { with leukemia }\end{array}$ \\
\hline Benzo(a)pyrene * & $\begin{array}{l}\text { Causes tumors in animals; birth } \\
\text { defects }\end{array}$ & $\begin{array}{l}\text { Dermatitis; regressive } \\
\text { verrucae (i.e., warts); } \\
\text { skin tumors in animals }\end{array}$ & $\begin{array}{l}\text { Causes tumors in } \\
\text { animals }\end{array}$ \\
\hline Beryllium & $\begin{array}{l}\text { Ulcerative gastrointestinal } \\
\text { lesions }\end{array}$ & $\begin{array}{l}\text { Dermatitis; skin } \\
\text { granulomas }\end{array}$ & $\begin{array}{l}\text { Nasopharyngitis; } \\
\text { shortness of breath; } \\
\text { labored breathing; } \\
\text { chemical pneumonitis }\end{array}$ \\
\hline Cadmium & $\begin{array}{l}\text { Renal tubular damage; increased } \\
\text { risk of bone fractures }\end{array}$ & $\begin{array}{l}\text { No known dermal health } \\
\text { effects }\end{array}$ & $\begin{array}{l}\text { Decreased lung function; } \\
\text { emphysema }\end{array}$ \\
\hline Copper & Nausea; vomiting; diarrhea & Dermatitis & $\begin{array}{l}\text { Irritation to eyes, nose, } \\
\text { pharynx; nasal septum } \\
\text { perforation }\end{array}$ \\
\hline Dibromochloromethane * & $\begin{array}{l}\text { Nervous system disorders; liver } \\
\text { and kidney disease }\end{array}$ & $\begin{array}{l}\text { Skin irritation; potential } \\
\text { occupational carcinogen }\end{array}$ & $\begin{array}{l}\text { Mucous membranes and } \\
\text { upper respiratory tract } \\
\text { irritation }\end{array}$ \\
\hline 1,2-Dichloroethane * & $\begin{array}{l}\text { Nervous system disorders; liver } \\
\text { and kidney disease }\end{array}$ & $\begin{array}{l}\text { Skin lesions; pulmonary } \\
\text { tumors; potential } \\
\text { occupational carcinogen }\end{array}$ & Lung effects \\
\hline Heptachlor * & $\begin{array}{l}\text { Liver damage; neurological } \\
\text { effects; reproductive system } \\
\text { dysfunction }\end{array}$ & $\begin{array}{l}\text { Potential occupational } \\
\text { carcinogen }\end{array}$ & $\begin{array}{l}\text { Nervous and immune } \\
\text { system effects }\end{array}$ \\
\hline Heptachlor Epoxide * & $\begin{array}{l}\text { Liver damage; neurological } \\
\text { effects; reproductive system } \\
\text { dysfunction }\end{array}$ & $\begin{array}{l}\text { Potential occupational } \\
\text { carcinogen }\end{array}$ & $\begin{array}{l}\text { Nervous and immune } \\
\text { system effects }\end{array}$ \\
\hline Iron & $\begin{array}{l}\text { No known ingestion health } \\
\text { effects }\end{array}$ & $\begin{array}{l}\text { No known dermal health } \\
\text { effects }\end{array}$ & Benign pneumoconiosis \\
\hline Lead * & $\begin{array}{l}\text { Malnutrition; constipation, } \\
\text { abdominal pain, colic; } \\
\text { neurological impairment }\end{array}$ & $\begin{array}{l}\text { No known dermal health } \\
\text { effects }\end{array}$ & $\begin{array}{l}\text { Encephalopathy; } \\
\text { neurological effects }\end{array}$ \\
\hline Manganese & Adverse neurological effects & $\begin{array}{l}\text { No known dermal health } \\
\text { effects }\end{array}$ & $\begin{array}{l}\text { Difficulty breathing; } \\
\text { neurological disorder }\end{array}$ \\
\hline Nitrite as $\mathbf{N}$ & $\begin{array}{l}\text { Methemoglobinemia; } \\
\text { abdominal cramps; vomiting }\end{array}$ & $\begin{array}{l}\text { No known dermal health } \\
\text { effects }\end{array}$ & $\begin{array}{l}\text { No known inhalation } \\
\text { effects }\end{array}$ \\
\hline Pentachlorophenol * & Weakness; nausea; vomiting & $\begin{array}{l}\text { Dermatitis; skin lesions; } \\
\text { liver effects; renal effects }\end{array}$ & $\begin{array}{l}\text { Irritation to eyes, nose, } \\
\text { throat; sneezing, cough; } \\
\text { difficulty breathing }\end{array}$ \\
\hline Thallium & $\begin{array}{l}\text { Vomiting; diarrhea; liver and } \\
\text { kidney damage }\end{array}$ & Alopecia (hair loss) & $\begin{array}{l}\text { Nervous system effects; } \\
\text { pulmonary edema }\end{array}$ \\
\hline Vinyl chloride * & $\begin{array}{l}\text { Gastrointestinal bleeding; } \\
\text { enlarged liver }\end{array}$ & $\begin{array}{l}\text { Skin thickening; frostbite; } \\
\text { potential occupational } \\
\text { carcinogen }\end{array}$ & Liver cancer \\
\hline
\end{tabular}

* Indicates carcinogenic contaminants.

Flowback water spill volumes were obtained from the United States Coast Guard (USCG) National Response Center's website, which keeps records of spills and chemical releases each year as well as information about the incident such as the type of contaminant released, the volume spilled, whether the spill reached water, and the portion of the volume that reached water [54]. A distribution of flowback water spill volumes and the volumes that reached water can be found in Figure 1. For this analysis, spill data from 2008 to 2016 were collected and filtered for only spills of flowback water or shale gas production water. As the scenario examined in this assessment involves flowback reaching drinking water, only spills that reached water were considered (Figure 1).

Oracle Crystal Ball (Oracle ${ }^{\circledR}$, Redwood Shores, CA, USA) was used to fit statistical distributions to the spill data and to the flowback water constituent concentration data described above. Crystal Ball was then used to conduct a Monte Carlo analysis using 1000 simulated values for each variable, resulting in a discrete distribution of 1000 results for each cancer risk and hazard quotient calculation. 
A list of input variables used in the Monte Carlo simulation can be found in Table 2, along with the type of distribution used to fit the data, the number of samples in the distribution, median and 95th percentile values for each distribution, and the data source for each variable.
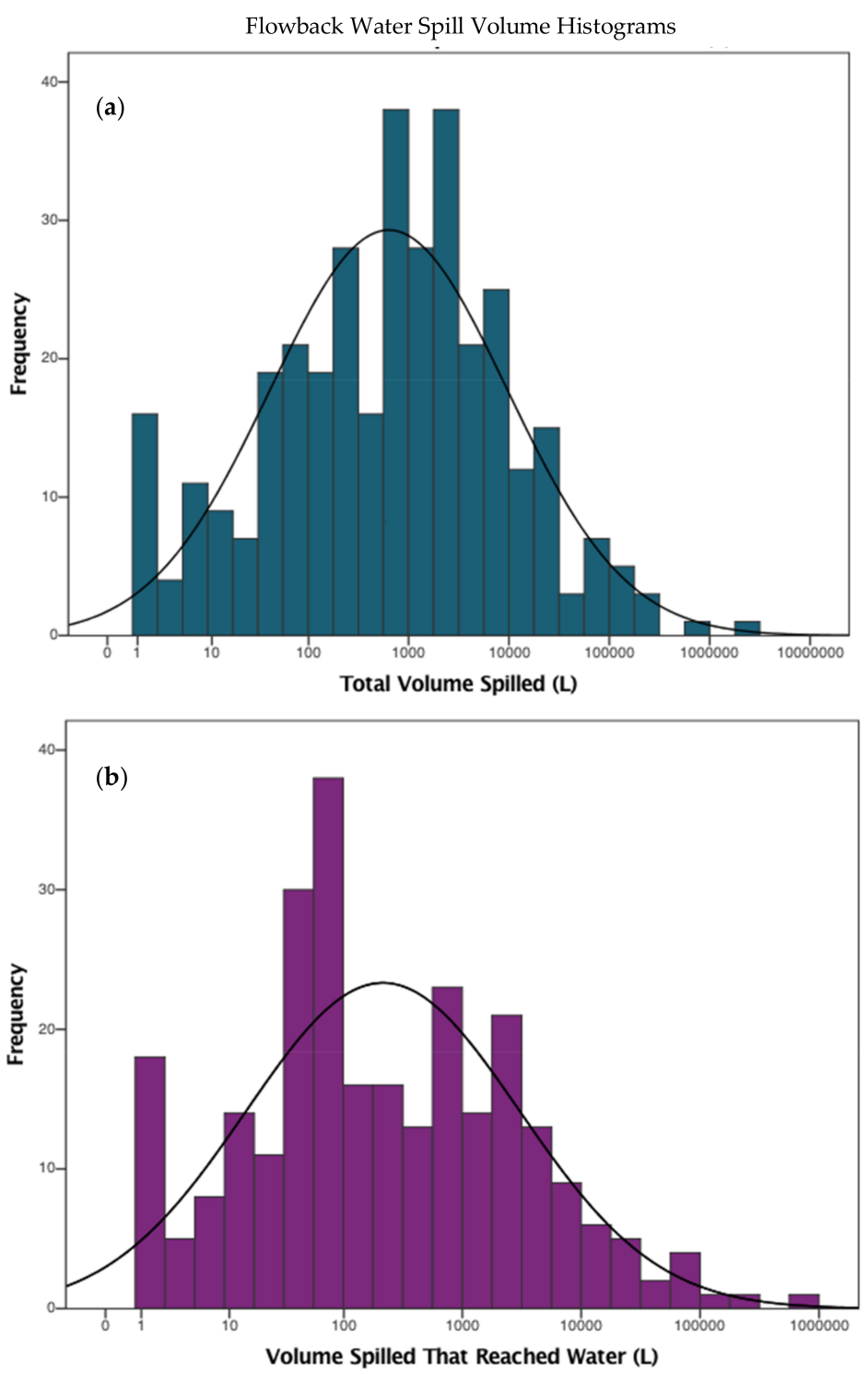

Figure 1. Histogram of flowback water spills that reached water showing (a) the total volume spilled and (b) the volume that reached water. Annual datasets collected between 2000 and 2016 [54] (Retrieved March 2016).

Table 2. Distribution median and 95th percentile values for Monte Carlo simulation assumption variables.

\begin{tabular}{|c|c|c|c|c|}
\hline Monte Carlo Simulation Input Variables & $N$ & Distribution & Median & 95th $\%$ \\
\hline Flowback Water Spill Volume (L) ${ }^{1}$ & 194 & Lognormal & 128.00 & $114,900.00$ \\
\hline Aluminum Concentration $(\mathrm{mg} / \mathrm{L})^{2}$ & 220 & Lognormal & 0.29 & 2.80 \\
\hline Antimony Concentration $(\mathrm{mg} / \mathrm{L})^{2}$ & 186 & Triangular & 0.05 & 0.09 \\
\hline Arsenic Concentration $(\mathrm{mg} / \mathrm{L})^{2}$ & 219 & Logistic & 0.05 & 0.09 \\
\hline Barium Concentration $(\mathrm{mg} / \mathrm{L})^{2}$ & 220 & Lognormal & 164.00 & $20,009.00$ \\
\hline Benzene Concentration $(\mathrm{mg} / \mathrm{L})^{2}$ & 123 & Lognormal & 0.01 & 0.17 \\
\hline Benzo(a)pyrene Concentration $(\mathrm{mg} / \mathrm{L})^{2}$ & 111 & Logistic & 0.01 & 0.01 \\
\hline
\end{tabular}


Table 2. Cont.

\begin{tabular}{|c|c|c|c|c|}
\hline Monte Carlo Simulation Input Variables & $N$ & Distribution & Median & 95th $\%$ \\
\hline Beryllium Concentration $(\mathrm{mg} / \mathrm{L})^{2}$ & 216 & Minimum Extreme & 0.02 & 0.01 \\
\hline Cadmium Concentration $(\mathrm{mg} / \mathrm{L})^{2}$ & 218 & Lognormal & 0.01 & 0.06 \\
\hline Copper Concentration $(\mathrm{mg} / \mathrm{L})^{2}$ & 219 & Lognormal & $33,500.00$ & 0.45 \\
\hline 1,2-Dichloroethane Concentration $(\mathrm{mg} / \mathrm{L})^{2}$ & 143 & Lognormal & 0.01 & 0.02 \\
\hline Heptachlor Concentration $(\mathrm{mg} / \mathrm{L})^{2}$ & 73 & Pareto & 0.01 & 0.02 \\
\hline Heptachlor Epoxide Concentration $(\mathrm{mg} / \mathrm{L})^{2}$ & 73 & Lognormal & 0.01 & 0.02 \\
\hline Iron Concentration $(\mathrm{mg} / \mathrm{L})^{2}$ & 233 & Lognormal & 29.70 & 178.20 \\
\hline Lead Concentration $(\mathrm{mg} / \mathrm{L})^{2}$ & 212 & Lognormal & 0.03 & 0.20 \\
\hline Manganese Concentration $(\mathrm{mg} / \mathrm{L})^{2}$ & 220 & Lognormal & 2.17 & 12.40 \\
\hline Nitrite as N Concentration $(\mathrm{mg} / \mathrm{L})^{2}$ & 91 & Lognormal & 0.11 & 060.81 \\
\hline Pentachlorophenol Concentration $(\mathrm{mg} / \mathrm{L})^{2}$ & 111 & Weibull & 0.01 & 0.02 \\
\hline Thallium Concentration $(\mathrm{mg} / \mathrm{L})^{2}$ & 192 & Weibull & 0.02 & 0.28 \\
\hline Radium-226 Concentration (PCi/L) ${ }^{2}$ & 34 & Lognormal & 1.30 & $48,190.20$ \\
\hline Radium-228 Concentration $(\mathrm{PCi} / \mathrm{L})^{2}$ & 30 & Lognormal & 0.23 & 4470.00 \\
\hline
\end{tabular}

${ }^{1}$ Data collected from USCG [54]; ${ }^{2}$ Data collected from Abualfaraj et al. [33]. Ci $=$ Curie.

\subsection{Residential Risk Assessment for Carcinogens}

Equations used for cancer risk following exposure to chemicals in residential drinking water were taken from the EPA's Risk Assessment Guidance for Superfund (RAGS) [50]. This guidance provides methods and equations for conducting human health risk assessments, as well as recommended values for certain parameters required for calculations. The residential drinking water exposure pathways considered are ingestion, inhalation of volatiles, and dermal exposure through showering/bathing. The guidance includes equations for the ingestion and inhalation routes, while specific procedures to assess exposure and risk from the dermal pathway are provided in the Supplemental Guidance for Dermal Risk Assessment (Part E) [55]. The Supplemental Guidance for Inhalation Risk Assessment (Part F) was also used to calculate toxicity factors for volatile compounds in flowback water (Exhibit B3).

Excess lifetime cancer risk, the increase in the probability of developing cancer over a lifetime, is estimated by multiplying the dose by a chemical-specific toxicity factor (slope factor) for each exposure route. Appendix A presents definitions and inputs for the variables used in cancer risk estimation (Tables A1 and A2), as well as ingestion cancer toxicity values for the ten carcinogens examined (Table A3). Dermal Absorption Factors and Inhalation Unit Risk values are also presented in Table A3 and are used to calculate dermal and inhalation slope factors (Exhibits B2 and B3). The equations for estimating cancer risk in the EPA's RAGS guidance for ingestion, dermal, and inhalation risk are shown in Appendix B.

The flowback water sampling data utilized in this study include two high-priority radioisotopes (radium-226 and radium-226). Procedures for estimating excess lifetime cancer risk from Part B of the Risk Assessment Guidance for Superfund are presented in Exhibits B4 [56]. Carcinogenicity slope factors for radionuclides (Table A4) were obtained from the Office of Radiation Programs' Federal Guidance No. 11 [57]. The RAGS guidance does not recommend combining cancer risk from radionuclides with other carcinogens when calculating total risk due to the differences in the equations used and the methods for determining slope factors for radionuclides. Results for radionuclides are, therefore, presented separately.

\subsection{Residential Toxicity Assessment for Non-Carcinogens}

Hazard Quotients, the ratio of exposure to the estimated daily exposure level at which no adverse health effects are likely to occur, are calculated for non-carcinogenic parameters in flowback water. Ingestion, dermal, and inhalation pathways are also considered for non-carcinogens using equations in the EPA's RAGS $[50,55,58]$. Definitions and inputs for variables used in this estimation are presented in Appendix A (Tables A1 and A2). Reference toxicity factors (reference dose) for ingestion and inhalation of contaminants in water are presented in Table A3. Reference doses for dermal exposure are calculated based on the dermal absorption factor and equations presented in Exhibit B2b. 
Totals from all three exposure pathways are computed to estimate the total cancer risk and total hazard index for each contaminant. Totals for each pathway for all contaminants are also computed and summed to estimate the total cancer risk and total hazard index (HI), where:

$$
\begin{aligned}
& \text { Total cancer risk = Ingestion Risk + Inhalation Risk + Dermal Risk } \\
& \text { Total Hazard Index = Ingestion HI + Inhalation HI + Dermal HI }
\end{aligned}
$$

\section{Results}

\subsection{Residential Exposure from Tap-Water}

Excess lifetime cancer risks from ingestion, dermal, and inhalation exposure to the 10 carcinogenic high-priority constituents in flowback water are presented in Figure 2 as a range of values based on the 1000 trials generated by the Monte Carlo simulation. None of the contaminants exceed the target risk of developing cancer $\left(10^{-6}\right)$ at the median value. However, the upper limit of risk for several constituents exceeds the cancer risk target. Ingestion risk from exposure to arsenic, benzo(a)pyrene, heptachlor, heptachlor epoxide, pentachlorophenol, and vinyl chloride exceed acceptable lifetime cancer risk, with arsenic having the highest 95th percentile value $\left(\sim 10^{-4}\right)$. This can be expressed as the risk of one incremental increase in cancer occurrence for every ten thousand people exposed to arsenic under similar conditions.

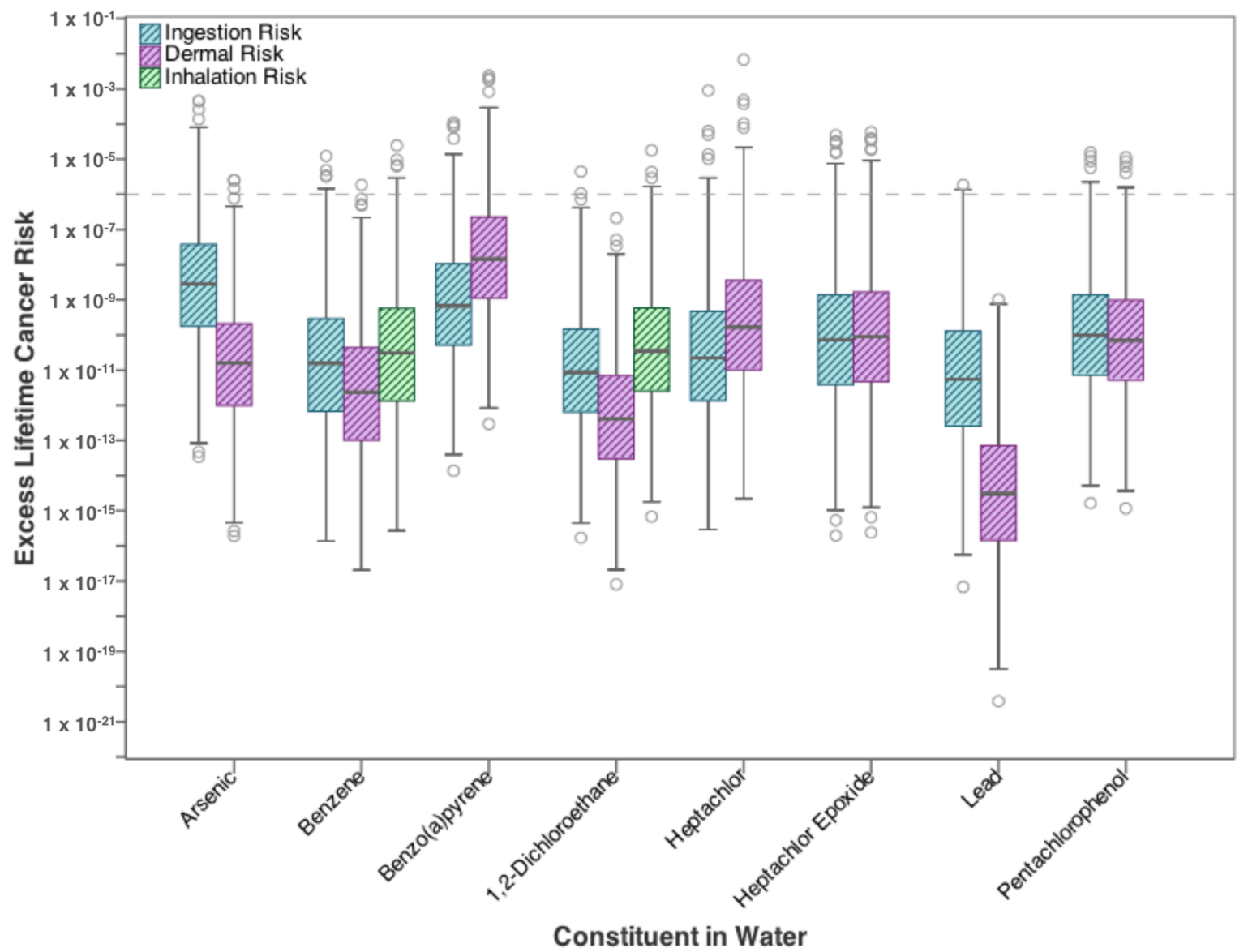

Figure 2. Excess lifetime cancer risk from drinking water exposure to high-priority carcinogenic contaminants found in flowback water. 
Of the three volatile carcinogens analyzed, only benzene exceeds the target cancer risk, and only between the 95th percentile and the maximum value, where cancer occurrence increases by one for every hundred thousand exposed individuals compared to the unexposed general population. Risk from the dermal exposure route, similarly to the ingestion pathway, exceeds target cancer risk at the upper limit for the following constituents: benzene, benzo(a)pyrene, heptachlor, heptachlor epoxide, and pentachlorophenol.

Hazard Quotients (HQ) for non-carcinogenic constituents in flowback water are shown in Figure 3. The hazard quotient provides a ratio of the concentration in relation to the reference dose for each parameter with non-carcinogenic adverse health effects, which is then compared to 1, the acceptable target value. It appears from Figure 3 than non-carcinogens found in flowback water pose a much smaller threat to human health than the carcinogenic contaminants in Figure 2. Only two constituents exceeded the target HQ of 1 and only at the upper bound; they are barium and thallium. Risk from both ingestion and dermal exposure to barium exceed the target, while only ingestion of thallium exceeds the target, at the 95th percentile values. Ingestion of barium and thallium can cause nausea and vomiting, liver damage, and nervous system effects (Table 1).

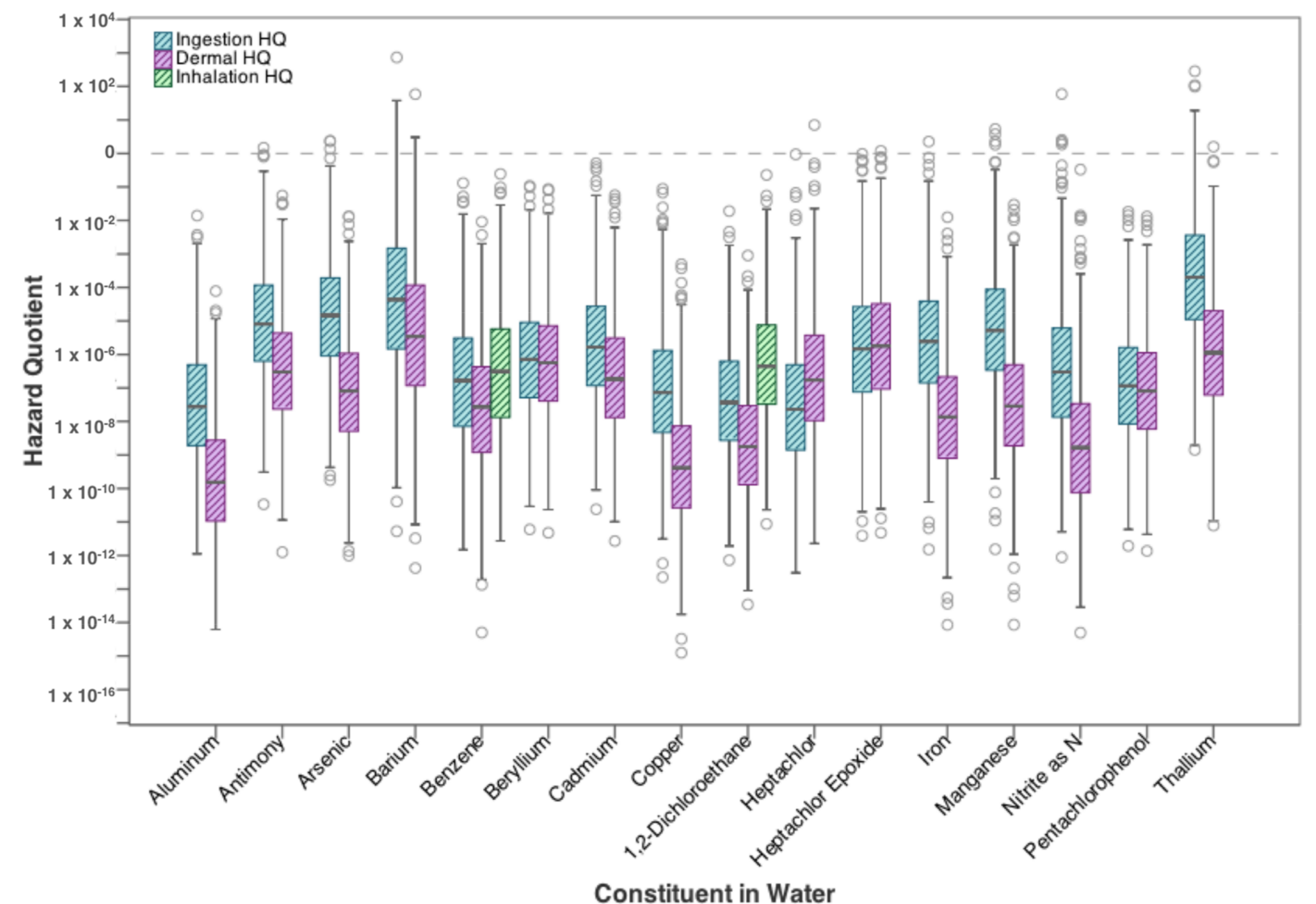

Figure 3. Hazard Quotient from drinking water exposure to high-priority non-carcinogenic contaminants found in flowback water.

Figure 4 combines risk and HQ values from all three exposure pathways in order to calculate the total cancer risk and total Hazard Index from residential exposure to each contaminant of concern in flowback water. Again, cancer risk and HI values are compared to their target values of $10^{-6}$ and 1 , respectively. The distributions for both cancer risk and HI generally fall below the target limits, with only maximum values and 4th quartile ranges for some parameters exceeding targets. For carcinogens benzene, benzo(a)pyrene, heptachlor, heptachlor epoxide, pentachlorophenol, and vinyl chloride, all have upper-bound concentrations that exceed risks of $10^{-6}$. For non-carcinogens, similarly to Figure 3, only upper bound (95th percentile) estimates of $\mathrm{HI}$ values for barium and thallium exceed 1 . 


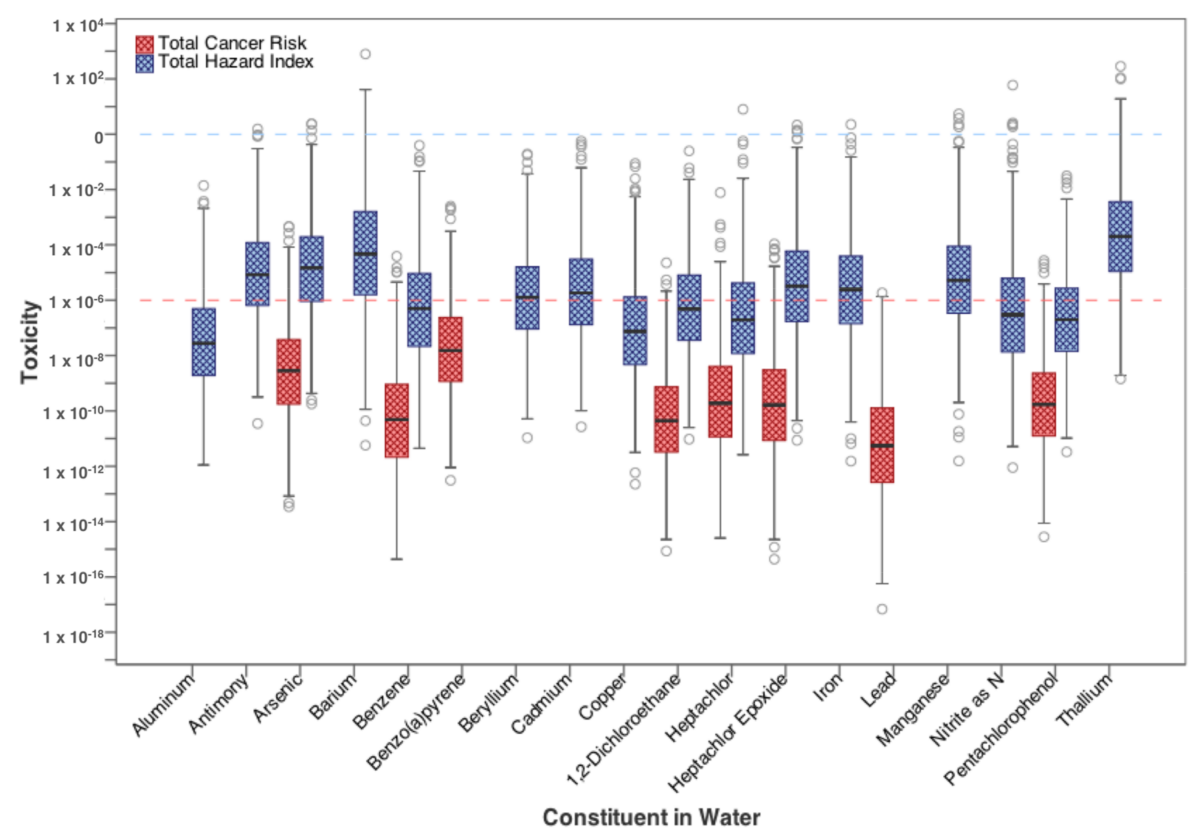

Figure 4. Total cancer risk and total hazard quotient from drinking water ingestion, inhalation, and dermal exposure to high-priority contaminants found in flowback water.

Figure 5, on the other hand, combines cancer risk and toxicity values of all the carcinogenic and non-carcinogenic constituents for each exposure pathway. In this way, the pathway of most concern can be identified in terms of exposure to high-priority constituents found in flowback water. Figure 5 also includes total cancer risk and the total hazard index for all three pathways combined for all 20 flowback water constituents examined. In both cases, the total risk and total HI are controlled by the exposure pathways of most concern: dermal exposure for carcinogens and ingestion for non-carcinogens.

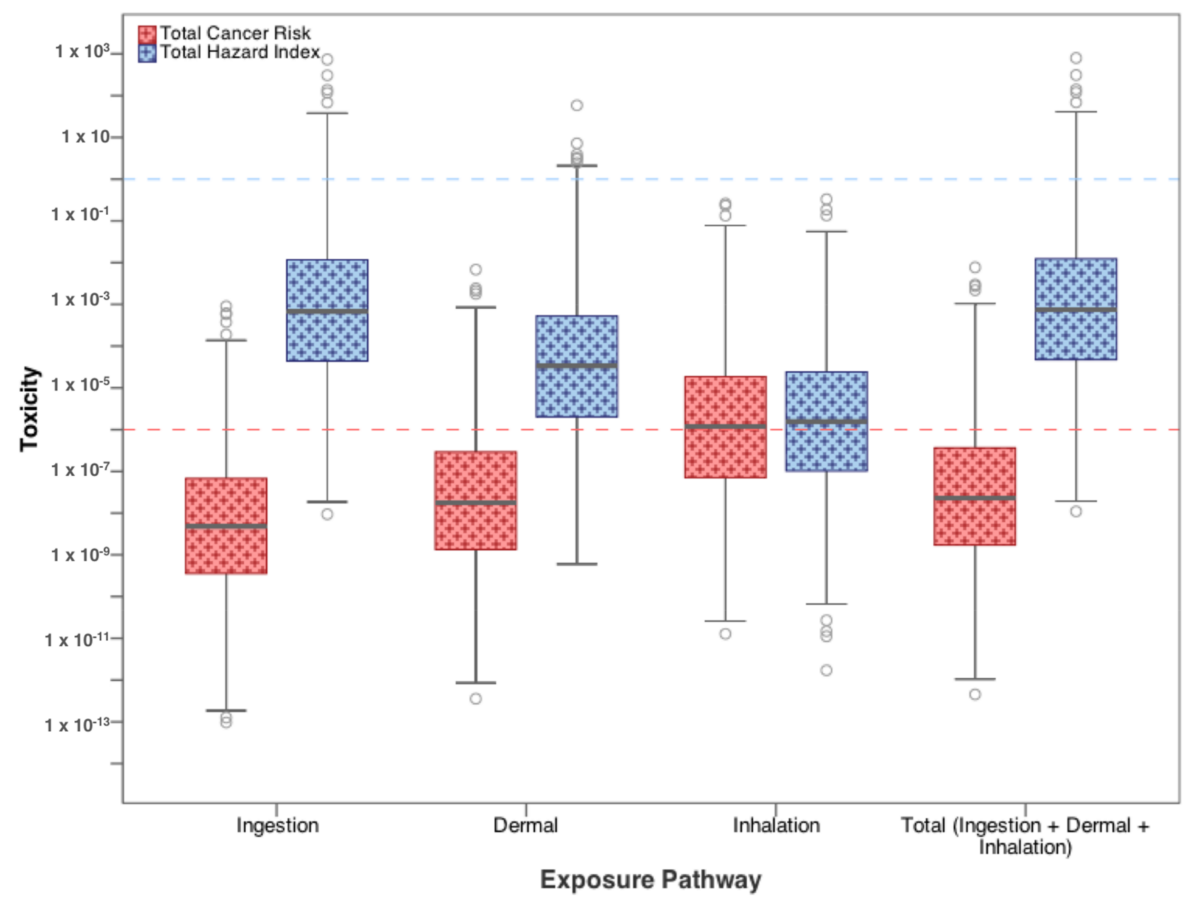

Figure 5. Total cancer risk and hazard index for each drinking water exposure pathway for high-priority contaminants found in flowback water (see Table A3 for list of contaminants included in total). 
By varying the exposure duration for each pathway, the maximum possible exposure duration before risk and toxicity values exceed limits were calculated (Tables 3 and 4). Exposure to carcinogens in flowback water through residential drinking water for as little as 39 days can result in significantly increase cancer risk, assuming the upper bound (95th percentile) on spill volume and contaminant concentration in flowback (Table 3). For non-carcinogens, exposure for up to 31 weeks will not result in adverse health effects with an HI exceeding 1, even at upper bound values for exposure (Table 4).

Table 3. Maximum Exposure Duration (ED) for each scenario and exposure pathway where maximum possible values of cancer risk remain below the target value $\left(<10^{-6}\right)$.

\begin{tabular}{ccc}
\hline \multirow{2}{*}{ Exposure Pathway } & \multicolumn{2}{c}{ Maximum Exposure Duration (ED) } \\
\cline { 2 - 3 } & Drinking Water Scenario & Swimming Scenario \\
\hline Total Ingestion Cancer Risk & 120 days & 16.5 years \\
Total Dermal Cancer Risk & 68 days & 55 days \\
Total Inhalation Cancer Risk & 1.2 years & 2.1 years \\
Total Risk (Ingestion + Dermal + Inhalation) & 39 days & 49 days \\
Total Radionuclide Cancer Risk & $8 \mathrm{~h}$ & 11 days \\
\hline
\end{tabular}

Table 4. Maximum ED for each pathways and scenario where total non-carcinogenic hazard index remains below the target value $(<1.0)$.

\begin{tabular}{ccc}
\hline \multirow{2}{*}{ Exposure Pathway } & \multicolumn{2}{c}{ Maximum Exposure Duration (ED) } \\
\cline { 2 - 3 } & Drinking Water Scenario & Swimming Scenario \\
\hline Ingestion Hazard Quotient & 36 weeks & 56 years \\
Dermal Hazard Quotient & 17 years & 12 years \\
Inhalation Hazard Quotient & $>100$ years & $>100$ years \\
Hazard Index (Ingestion + Dermal + Inhalation) & 31 weeks & 9 years \\
\hline
\end{tabular}

Figures 6 and 7 show the increase in cancer risk from exposure to radionuclides in residential drinking water. In Figure 6, risks from each exposure pathway for radium-226 and radium-228 are presented. For both radioisotopes, inhalation poses the highest risk, where the median values for both parameters exceed the target value of $10^{-6}$. Median dermal risk from exposure to radionuclides, defined as immersion in water, approached $10^{-6}$ for radium-226, while radium-228 exceeds the target value at the 75th percentile (Q3). Ingestion risk from both radionuclides exceeds the $10^{-6}$ target value only at the upper limits (between Q3 and the upper whisker). Combining both radioisotopes shows that the total risk from exposure to radionuclides in water is governed by the inhalation risk (Figure 7). The range for each pathway individually exceeds the target lifetime risk at some level, in fact, the inhalation risk exceeds $10^{-6}$ even at the 25 th percentile value, as does the total risk from all three pathways combined. 


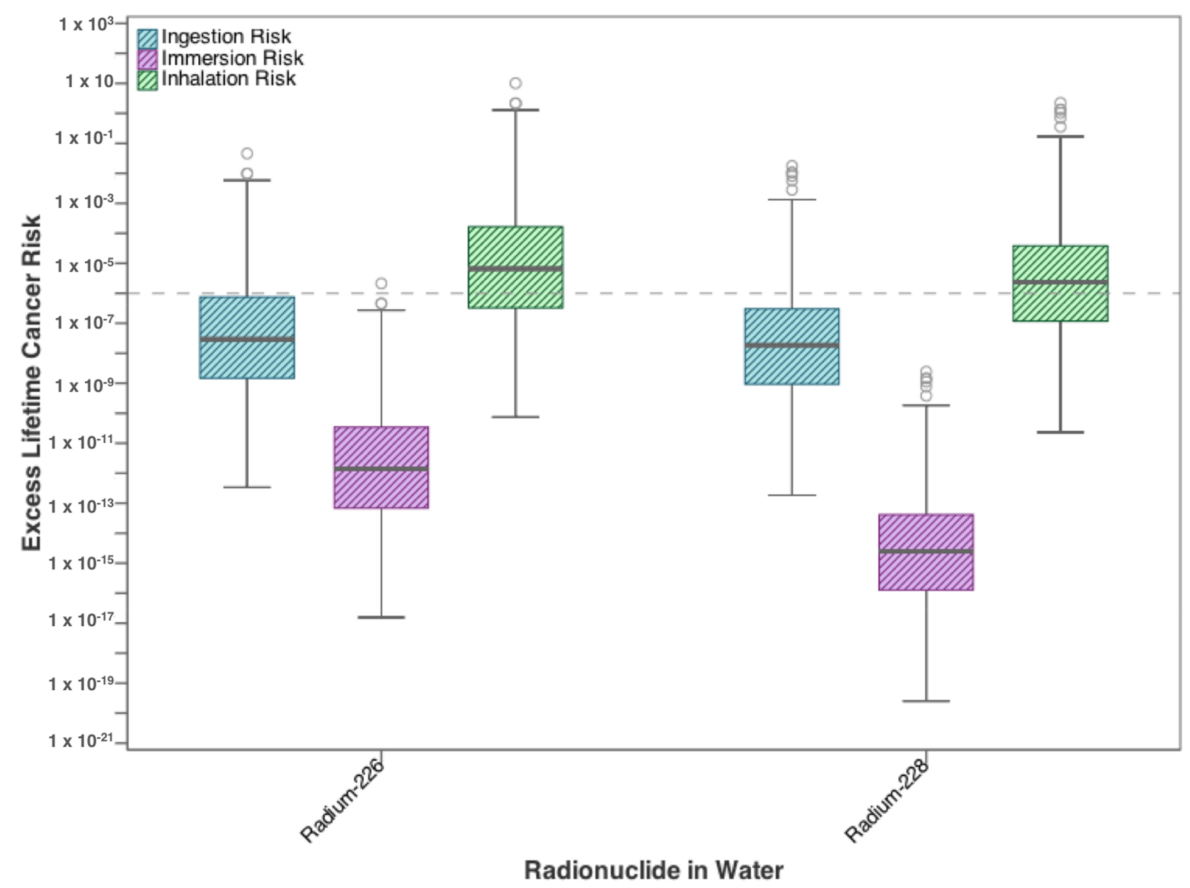

Figure 6. Excess lifetime cancer risk from drinking water exposure to high priority radionuclides found in flowback water.

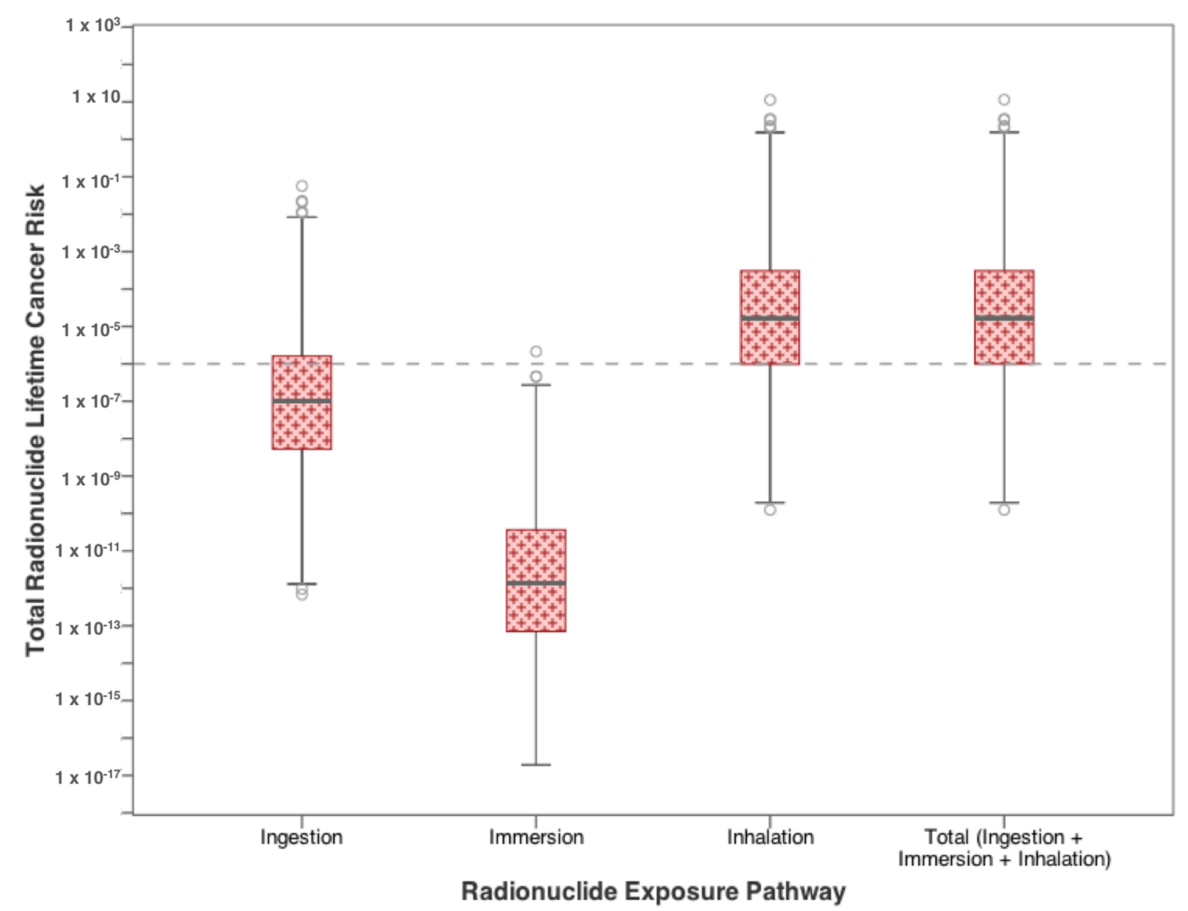

Figure 7. Total cancer risk from drinking water exposure to high-priority radionuclides (radium-226 and radium-228) found in flowback water.

\subsection{Residential Exposure from Swimming}

Only the outlier values for risk from the swimming scenario exceeds $10^{-6}$ and only from the dermal pathway. In fact, increasing the exposure from $1 \mathrm{~h} /$ day for up to 49 days still does not increase the upper bound (95th percentile) risk to above target values (Table 3). Figure 8 shows the total cancer risk and total hazard index from exposure to flowback water in a small fresh water pond by swimming 
in the pond once for one hour. Figure 9 shows the total cancer risk from exposure to radionuclides in flowback water from swimming in a contaminated pond for one hour. In both figures, the pathway of most concern is the inhalation pathway, which exceeds the target values even at median concentrations, while the dermal and ingestion pathways are below target values.

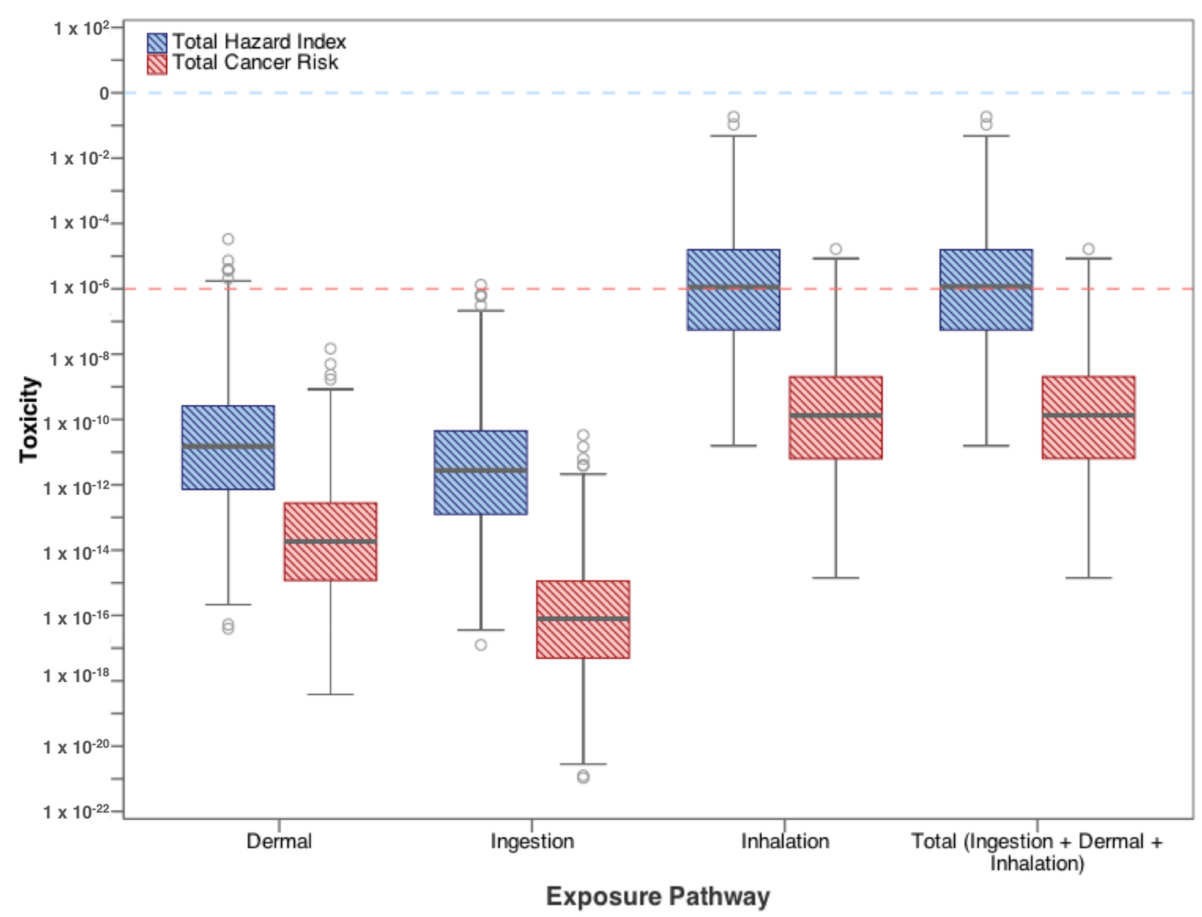

Figure 8. Total cancer risk and hazard index from swimming exposure to high priority contaminants in flowback water.

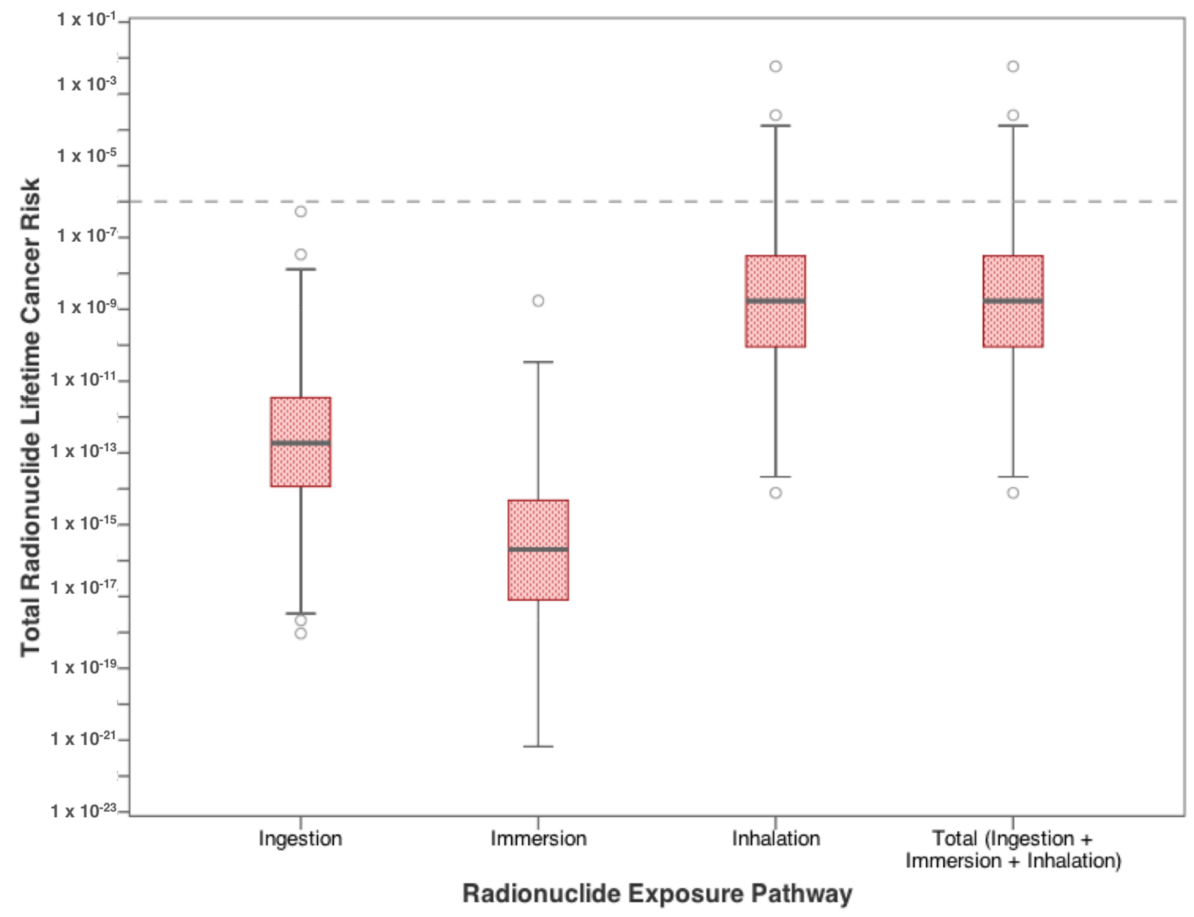

Figure 9. Total cancer risk from exposure pathways to high priority radionuclides from swimming in flowback water. 


\subsection{Uncertainty}

In order to better understand the impact each exposure parameter has on the results of the risk model, the Spearman's Rank Order correlation coefficient was calculated between the input and output variables of the Monte Carlo simulation. The correlation coefficients presented in Table 5 show that the volume of flowback water spilled has the strongest relationship with the total cancer risk and the total hazard index of all the input variables.

Table 5. Spearman's Rank Order correlation coefficient between input and output variables defined in the Monte Carlo Simulation.

\begin{tabular}{lcc}
\hline \multirow{2}{*}{ Input Variables } & \multicolumn{2}{c}{ Spearman's $Q$-Output Variables } \\
\cline { 2 - 3 } & Total Cancer Risk & Total Hazard Index \\
\hline Flowback Water Spill Volume (L) & $0.975^{* *}$ & $0.915^{* *}$ \\
Aluminum Concentration (mg/L) & 0.046 & 0.027 \\
Antimony Concentration (mg/L) & 0.005 & 0.000 \\
Arsenic Concentration (mg/L) & 0.016 & 0.032 \\
Barium Concentration (mg/L) & 0.043 & $0.184^{* *}$ \\
Benzene Concentration (mg/L) & $0.053^{*}$ & 0.034 \\
Benzo(a)pyrene Concentration (mg/L) & $0.061^{*}$ & 0.019 \\
Beryllium Concentration (mg/L) & 0.028 & $0.057^{*}$ \\
Cadmium Concentration (mg/L) & 0.012 & 0.039 \\
Copper Concentration (mg/L) & 0.007 & 0.016 \\
Dibromochloromethane Concentration (mg/L) & 0.034 & $0.055^{*}$ \\
1,2-Dichloroethane Concentration (mg/L) & 0.048 & $0.057^{*}$ \\
Heptachlor Concentration (mg/L) & 0.025 & 0.021 \\
Heptachlor Epoxide Concentration (mg/L) & 0.008 & 0.014 \\
Iron Concentration (mg/L) & 0.006 & 0.017 \\
Lead Concentration (mg/L) & 0.019 & 0.018 \\
Manganese Concentration (mg/L) & 0.010 & 0.022 \\
Nitrite as N Concentration (mg/L) & 0.013 & 0.022 \\
Pentachlorophenol Concentration (mg/L) & 0.032 & 0.030 \\
Thallium Concentration (mg/L) & 0.023 & $0.157^{* *}$ \\
Vinyl chloride Concentration (mg/L) & 0.015 & 0.016 \\
\hline
\end{tabular}

\begin{tabular}{lc}
\hline \multicolumn{1}{c}{ Input Variables } & Total Radionuclide Cancer Risk \\
\hline Flowback Water Spill Volume (L) & $0.901^{* *}$ \\
Radium-226 Concentration (PCi/L) & $0.362^{* *}$ \\
Radium-228 Concentration (PCi/L) & $0.142^{* *}$ \\
${ }^{* *}$ Correlation significant at the 0.01 level (1-tailed); ${ }^{*}$ Correlation is significant at the 0.05 level (1-tailed);
\end{tabular}

\section{Discussion}

The risk assessment conducted in this study provides a priority list for contaminants in flowback water that are likely to pose the greatest threat to human health. In general, the risk of developing cancer from this type of exposure is relatively low, with only values at the upper bound of the Monte Carlo simulation trial results exceeding target limits for excess lifetime cancer risk. Given that the variability in spill volumes was much greater than the variability in concentrations for each chemical, the output of the Monte Carlo simulation is governed by the spill volume. Correlating the input variables with the outcome variables shows that the flowback water volume has the strongest relationship with the total cancer risk and the total hazard index of all the input variables (Table 5). The spill data used in this study included 194 reported spill incidents of flowback that reached water from the National Response Center's (NRC) data, with volumes ranging from $<1 \mathrm{~L}$ to $350,000 \mathrm{~L}$. This large range of values results in spill size having the greatest effect on the results of this model. By varying the potential spill volume based on the NRC database, it was possible to calculate a maximum spill volume cutoff value at which no adverse effects from any exposure pathway can be expected. Considering the 30-year 
drinking water scenario where all other parameters are unchanged, flowback water spills less than $1300 \mathrm{~L}$ in volume do not pose a threat to human health from both carcinogenic and non-carcinogenic contaminants. However, for radionuclides, spill volumes as low as $500 \mathrm{~L}$ can still result in cancer risk exceeding the target value. This result can be generalized to other scenarios by considering that $500 \mathrm{~L}$ represents a 1 in 110,000 dilution in a pond of 44 million L. Scenarios which provide more than this level of dilution before ingestion are likely to contribute minimally to cancer risk even over long periods of time. Other scenarios providing differing dilution amounts or differing exposure duration could be quickly evaluated by noting that a linear cancer risk model is used here and hence risk is proportional to exposure duration and concentration (and so inversely proportional to dilution factor). For the swimming scenario, a spill of $15,000,000 \mathrm{~L}$ or greater would be required for total toxicity to exceed target values, however, this is greater than the maximum spill volume reported by the NRC $(350,000 \mathrm{~L})$.

Of the ten carcinogens examined in this assessment, benzene, benzo(a)pyrene, heptachlor, heptachlor epoxide, pentachlorophenol, and vinyl chloride are of concern at the upper-bound values. In addition to increasing the risk of developing cancer, chronic exposure to these constituents can have serious adverse effects on human health, including liver and kidney diseases, neurological damage, and compromised immunity. When considering different exposure pathways, dermal exposure through bathing or showering had the highest risk, while inhalation of volatiles from the water does not pose a serious threat considering only three of parameters included in the assessment were considered volatile (benzene, 1,2-dichloroethane, and vinyl chloride).

It should be noted, however, that while vinyl chloride poses a significant risk at the upper range of the distribution, vinyl chloride concentrations collected from the flowback sampling were mostly not detected as they were either present in flowback water at concentrations below the instrumental detection limit, or were not present at all. Less than $5 \%$ of samples had detected values of vinyl chloride, so it is not likely to be a component typically found in flowback water. In addition, the composition of flowback water will vary greatly due to differences in geological, geographical, and biological conditions. The list of high-priority contaminants was developed based on their concentrations relative to drinking water standards; this list will likely vary when applying site-specific conditions or with different samples of flowback water. Figure 10 examines the validity of this prioritization by comparing mean risk and toxicity values for each contaminant to its mean concentration/MCL (Maximum Contamination Level). The data for cancer risk and hazard index generally follow a positive linear relationship between both prioritization methods. The R-squared values, which measure the proportion of the variance predicted by the model, are relatively low for both parameters; $\left(R^{2}=\right.$ 0.64 and 0.26 for cancer risk and hazard index, respectively). While a simple ratio of concentration to MCL is related to risk, this analysis accounts for other factors, such as volatility, dermal absorption, toxicity, etc., that influence risk. Accordingly, prioritization conducted here, based on scenario analyses, is preferred over the concentration/MCL approach proposed in earlier research [33]. 


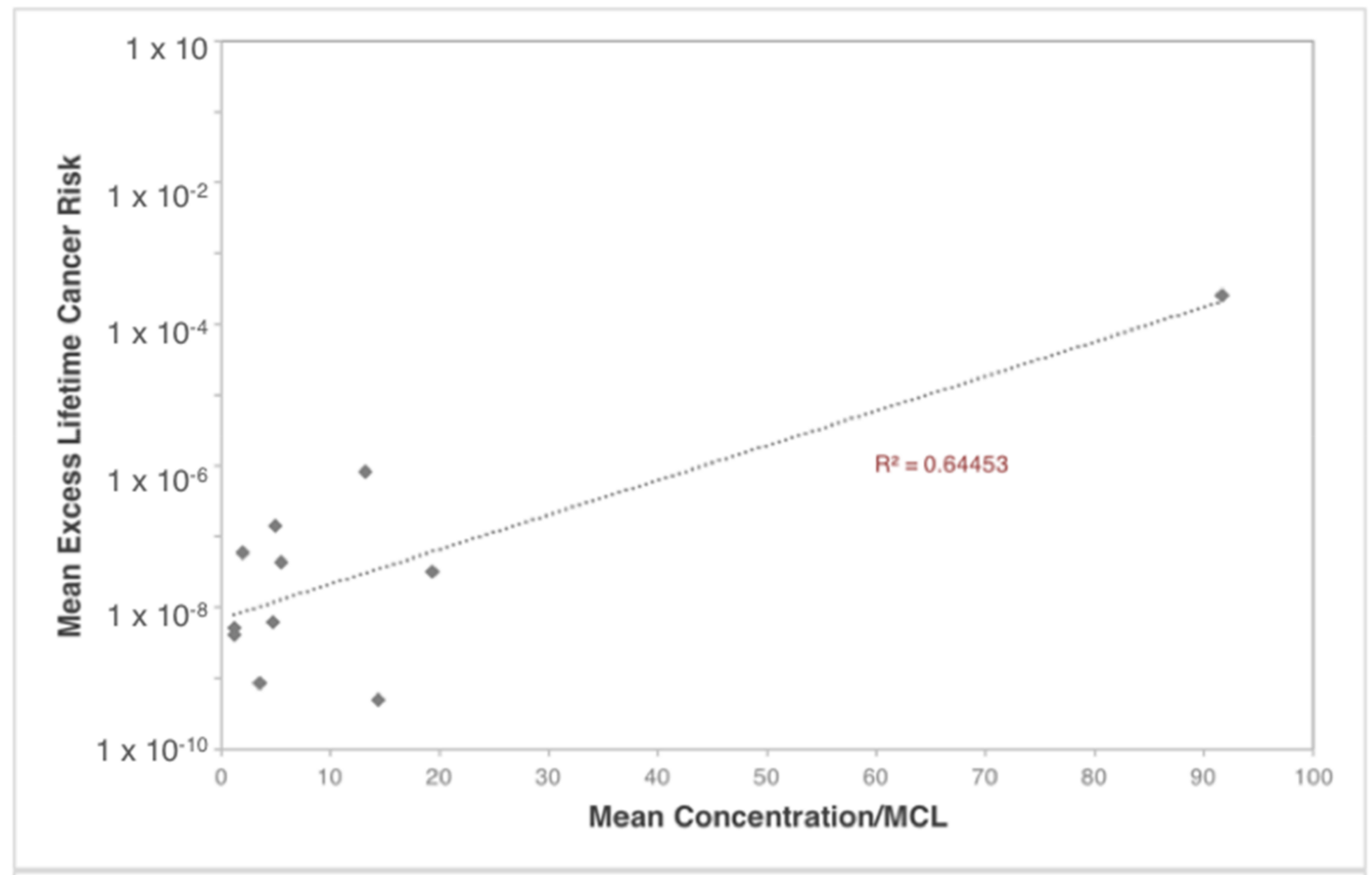

(a)

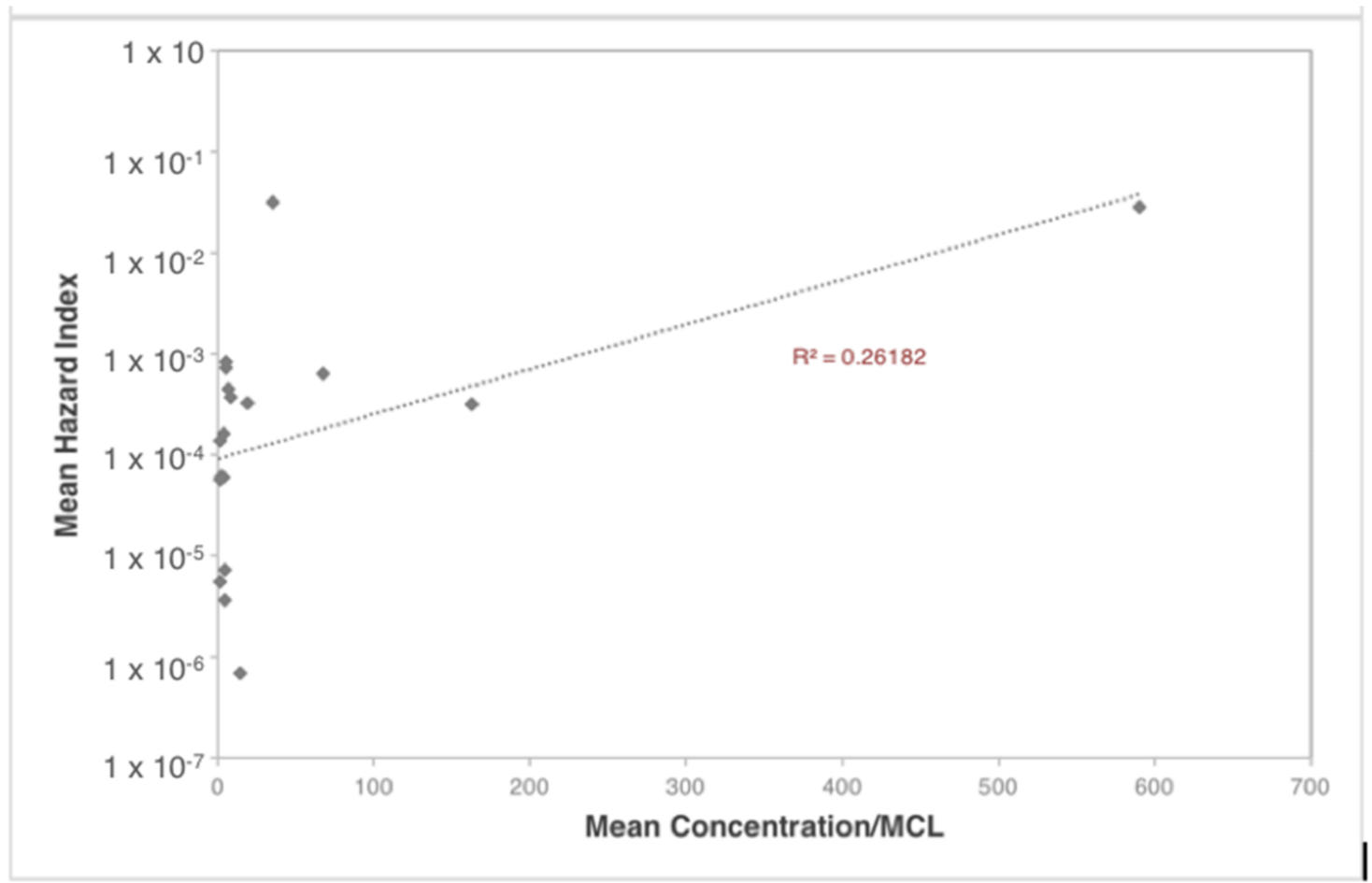

(b)

Figure 10. (a) Mean excess lifetime cancer risk and (b) mean hazard index for high-priority flowback water contaminants in residential drinking water vs. mean concentration/MCL for each contaminant. 
Systemic toxicity, expressed as the hazard quotient, from non-carcinogenic contaminants is not generally a concern in the scenarios considered here. Of the parameters considered, barium and thallium exceed the target ratio of 1 at the 95th percentile of the simulated values. Risk from ingestion of these elements poses the greatest threat to human health while toxicity from dermal exposure is much lower (Figures 3-5). While not classified as carcinogens, barium and thallium can have adverse health effects following chronic exposure, including gastrointestinal, respiratory, and nervous system effects (Table 1).

Radionuclides, which are known to exist in flowback and produced water as a result of occurring naturally within shale formations, pose a significant risk to human health and increase the likelihood of developing cancer in exposed individuals. Dermal and ingestion risk exceed limits at the higher end of their distributions, while median values for inhalation risk are at unacceptable levels. These exposures are due to radionuclides aerosolizing from water primarily during showering, based on the documented exposure factors developed by the EPA [57]. This exposure poses a significantly greater risk than any other contaminant included in this analysis and, therefore, should not be overlooked.

\section{Conclusions}

Based on the assumed 30-year exposure duration, the scenario presented in this assessment represents an extreme case as this would require a continuous source of contamination with similar volumes and concentrations. Reducing the exposure duration to 5 years reduces all 95th percentile values for total risk and total $\mathrm{HI}$ to below target values. The risk of cancer occurrence from radionuclide exposure, however, is still significant (greater than one in one million) for exposure durations as short as 2 weeks. While detailed hydrodynamic modeling is outside the scope of this study, even small water bodies may have residence times well above 2 weeks.

While it may require several years for residential exposure to some carcinogens in flowback water to result in adverse effects, exposure to radionuclides found in natural gas wastewater for only a few hours can pose significant risk to human health. Exposure to contaminated drinking water without notice or taking appropriate steps to remediate or treat the contamination for 30 years may not be a realistic scenario. However, exposure to certain compounds of flowback water for only a few hours or days is a much more likely scenario and can still present adverse effects. While there is evidence of flowback water being illegally disposed of, it is not likely to end up in fresh water supplies without attenuation or degradation, which are not considered in this study. Despite limitations, this assessment provides a preliminary prioritization of risk from different exposure pathways. This provides a useful tool for determining which chemicals will pose the greatest threat to human health, which can better provide insight into necessary precautions and preventative measures for managing and regulating the environmental impacts of shale gas development.

Author Contributions: N.A., M.S.O., and P.L.G. conceived of the study and designed the approach and analysis methodology. N.A. carried out the analysis with feedback from M.S.O. and P.L.G. and input on designing the model constraints and parameters. N.A. wrote the manuscript with input from M.S.O. and P.LG. All authors contributed to the research study and producing the final manuscript.

Conflicts of Interest: The authors declare no conflict of interest.h 


\section{Appendix A}

Table A1. Definitions for variables used in cancer risk and hazard quotient calculations.

\begin{tabular}{|c|c|c|}
\hline Variable & Variable Description & Source \\
\hline$A B S_{G I}$ & Fraction absorbed in gastrointestinal tract (dimensionless) & [33] \\
\hline$A T$ & Averaging time (70 years) & [55] \\
\hline$B$ & Correlation coefficient (dimensionless) & [55] \\
\hline$B W$ & Average adult body weight $(80 \mathrm{~kg})$ & [55] \\
\hline$D A D$ & Dermal absorbed dose (mg/kg.day) & [55] \\
\hline$C_{w}$ & Chemical concentration in water $\left(\mathrm{mg} / \mathrm{cm}^{3}\right)$ & Table 2; Equation (1) \\
\hline$F A$ & Fraction absorbed water (dimensionless) & [59] \\
\hline K & Volatilization rate $\left(0.5 \mathrm{~m}^{3} / \mathrm{L}\right)$ & [55] \\
\hline$K_{P}$ & Dermal permeability coefficient of compound in water $(\mathrm{cm} / \mathrm{h})$ & [49] \\
\hline IUR & Inhalation unit risk & Table A3 \\
\hline $\operatorname{RfC}_{i}$ & Inhalation reference concentration $\left(\mathrm{mg} / \mathrm{m}^{3}\right)$ & Table A3 \\
\hline$R f D_{A B S}$ & Absorbed reference dose $(\mathrm{mg} / \mathrm{kg} \cdot$ day $)$ & Table A3; Exhibit B2b \\
\hline$R f D_{i}$ & Inhalation reference dose $(\mathrm{mg} / \mathrm{kg} \cdot$ day $)$ & Table A3; Exhibit B3 \\
\hline$R f D_{O}$ & Oral reference dose $(\mathrm{mg} / \mathrm{kg} \cdot$ day $)$ & Table A3 \\
\hline$S F_{A B S}$ & Absorbed slope factor $(\mathrm{mg} / \mathrm{kg} \cdot \text { day })^{-1}$ & Table A3; Exhibit B2b \\
\hline$S F_{i}$ & Inhalation slope factor $(\mathrm{mg} / \mathrm{kg} \cdot \text { day })^{-1}$ & Table A3; Exhibit B3 \\
\hline$S F_{i m m}$ & Immersion slope factor $(\mathrm{mg} / \mathrm{kg} \cdot \text { day })^{-1}$ & Table A4 \\
\hline$S F_{O}$ & Oral slope factor $(\mathrm{mg} / \mathrm{kg} \cdot \text { day })^{-1}$ & Table A3 \\
\hline
\end{tabular}

Table A2. Inputs and definitions for exposure variable assumptions used in cancer risk and hazard quotient calculations.

\begin{tabular}{cccc}
\hline Variable & Variable Description & Value & Source \\
\hline$A T$ & Averaging time (years) & 70 years & {$[55]$} \\
$B W$ & Average adult body weight $(\mathrm{kg})$ & $80 \mathrm{~kg}$ & {$[55]$} \\
$E D$ & Exposure duration (years) & 30 years & {$[59]$} \\
$E F$ & Exposure frequency (days/year) & 350 days $/$ year & {$[49]$} \\
$E V$ & Event frequency (events/day) & 1 event/day & {$[49]$} \\
$I R_{w}$ & Daily water ingestion rate $(\mathrm{L} /$ day) & $2.5 \mathrm{~L} /$ day & {$[49]$} \\
$I R_{a}$ & Daily air inhalation rate $\left(\mathrm{m}^{3} /\right.$ day) & $15 \mathrm{~m}^{3} /$ day & {$[49]$} \\
$S A$ & Exposed skin surface area $\left(\mathrm{cm}^{2}\right)$ & $19,652 \mathrm{~cm}^{2}$ (avg. adult skin surface area) & {$[49]$} \\
$t^{*}$ & Time to reach steady-state $(\mathrm{h})$ & Chemical specific & Exhibit B3 \\
$t_{\text {event }}$ & Event duration (h/event) & Typical adult exposure $=0.71 \mathrm{~h} /$ day & {$[49]$} \\
$\tau_{\text {event }}$ & Lag time per event (h/event) & Chemical specific & Exhibit B3 \\
\hline
\end{tabular}


Table A3. Toxicity values for each parameter in water.

\begin{tabular}{|c|c|c|c|c|c|}
\hline Chemical & $\begin{array}{c}S F_{o} \\
{\text { (mg/kg-day })^{-1}}^{-1}\end{array}$ & $\begin{array}{c}R f D_{o} \\
\text { (mg/kg-day) }\end{array}$ & $A B S_{G I}$ & $\underset{\left(\mu \mathrm{g} / \mathrm{m}^{3}\right)}{\operatorname{IUR}}$ & $\begin{array}{c}R f C_{i} \\
\left(\mathrm{mg} / \mathrm{m}^{3}\right)\end{array}$ \\
\hline Aluminum & - & 1.0 & 1 & - & $5.0 \times 10^{-3}$ \\
\hline Antimony & - & $4.0 \times 10^{-4}$ & 0.15 & - & - \\
\hline Arsenic & 1.5 & $3.0 \times 10^{-4}$ & 1 & $4.3 \times 10^{-3}$ & $1.5 \times 10^{-5}$ \\
\hline Barium & - & $2.0 \times 10^{-1}$ & 0.07 & - & $5.0 \times 10^{-4}$ \\
\hline Benzene & $5.5 \times 10^{-2}$ & $4.0 \times 10^{-3}$ & 1 & $7.8 \times 10^{-6}$ & $3.0 \times 10^{-2}$ \\
\hline Benzo(a)pyrene & 7.3 & - & 1 & $1.10 \times 10^{-3}$ & - \\
\hline Beryllium & - & $2.0 \times 10^{-3}$ & 0.007 & $2.4 \times 10^{-3}$ & $2.0 \times 10^{-5}$ \\
\hline Cadmium & - & $5.0 \times 10^{-4}$ & 0.05 & $1.8 \times 10^{-3}$ & $1.0 \times 10^{-5}$ \\
\hline Copper & - & $4.0 \times 10^{-2}$ & 1 & - & - \\
\hline Dibromochloromethane & $8.4 \times 10^{-2}$ & $2.0 \times 10^{-2}$ & 1 & - & - \\
\hline 1,2-Dichloroethane & $9.1 \times 10^{-2}$ & $6.0 \times 10^{-3}$ & 1 & - & - \\
\hline Heptachlor & 4.5 & $5.0 \times 10-4$ & 1 & $2.6 \times 10^{-5}$ & $7.0 \times 10^{-3}$ \\
\hline Heptachlor Epoxide & 9.1 & $1.3 \times 10^{-5}$ & 1 & $1.3 \times 10^{-3}$ & - \\
\hline Iron & - & $7.0 \times 10^{-1}$ & 1 & $2.6 \times 10^{-3}$ & - \\
\hline Lead & $8.5 \times 10^{-3}$ & - & 1 & - & - \\
\hline Manganese & - & $2.4 \times 10^{-2}$ & 1 & $1.2 \times 10^{-5}$ & - \\
\hline Nitrite as N & - & $1.0 \times 10^{-1}$ & 1 & - & $5.0 \times 10^{-5}$ \\
\hline Pentachlorophenol & $4.0 \times 10^{-1}$ & $5.0 \times 10^{-3}$ & 1 & - & - \\
\hline Thallium & - & $1.0 \times 10^{-5}$ & 1 & $5.1 \times 10^{-6}$ & - \\
\hline Vinyl Chloride & $7.2 \times 10^{-1}$ & $3.0 \times 10^{-3}$ & 1 & - & - \\
\hline
\end{tabular}

Table A4. Toxicity values for radionuclides in water.

\begin{tabular}{ccccc}
\hline Radionuclide & $\begin{array}{c}S \boldsymbol{F}_{\boldsymbol{o}} \\
(\mathbf{R i s k} / \mathbf{P C i})\end{array}$ & $\begin{array}{c}\boldsymbol{S F _ { \boldsymbol { i } }} \\
\mathbf{( R i s k / P C i )}\end{array}$ & $\begin{array}{c}S F_{\text {imm }} \\
(\text { Risk/year } \text { per } \mathbf{P C i} / \mathbf{L})\end{array}$ & Source \\
\hline Radium-226 & $3.8 \times 10^{-10}$ & $2.82 \times 10^{-8}$ & $6.27 \times 10^{-14}$ & {$[57]$} \\
Radium-228 & $1.04 \times 10^{-9}$ & $4.37 \times 10^{-8}$ & $5.02 \times 10^{-16}$ & {$[57]$} \\
\hline
\end{tabular}

\section{Appendix B}

Exhibit B1a. Equations for estimating cancer risk and hazard quotient following ingestion of contaminants in residential drinking water [50].

Ingestion Cancer Risk $=\mathrm{CDI} \times S F_{0}$

Where:

Chronic Daily Intake $(C D I)=\frac{C_{w} \times I R_{w} \times E F \times E D}{A T \times 365(\text { days } / \text { year }) \times B W}$

Ingestion Hazard Quotient $=C D I / R f D_{0}$

Where:

Chronic Daily Intake $(C D I)=\frac{C_{w} \times I R_{w} \times E F \times E D}{E D \times 365(\text { days } / \text { year }) \times B W}$

Exhibit B1b. Sample calculation estimating cancer risk and hazard quotient following ingestion of residential drinking water with median concentration of Benzene [50].

Median concentration of benzene in drinking water $=3.75 \times 10^{-7} \mathrm{mg} / \mathrm{L}$

For carcinogenic effect:

Chronic Daily Intake $(C D I)=\frac{3.75 \times 10^{-7} \times 2.5 \times 350 \times 30}{70 \times 365 \times 80}=4.8 \times 10^{-9}$

Ingestion Cancer Risk $=C D I \times S F_{0}=4.8 \times 10^{-9} \times 5.5 \times 10^{-2}=2.65 \times 10^{-10}$

For non-carcinogenic effect:

Chronic Daily Intake $(C D I)=\frac{3.75 \times 10^{-7} \times 2.5 \times 350 \times 30}{30 \times 365 \times 80}=1.12 \times 10^{-8}$

Ingestion Hazard Quotient $=C D I / R f D_{o}=1.12 \times 10^{-8} / 4.0 \times 10^{-3}=2.8 \times 10^{-6}$ 
Exhibit B2a. Equations for estimating cancer risk and hazard quotient following dermal exposure to contaminants in residential drinking water [55].

Dermal Cancer Risk $=D A D \times S F_{A B S}$

Where:

$D A D_{\text {for inorganics }}=\frac{C_{w} \times K_{p} \times t_{\text {event }} \times E V \times E D \times E F \times S A}{A T \times 365 \text { (days } / \text { year }) \times B W}$

If $t_{\text {event }} \leq t^{*}$, then:

$D A D_{\text {for organics }}=\frac{2 \times F A \times K_{p} \times C_{w} \times \sqrt{\frac{6 \times \tau_{\text {event }} \times t_{\text {event }}}{\pi}} \times E V \times E D \times E F \times S A}{A T \times 365(\text { days } / \text { year }) \times B W}$

If $t_{\text {event }}>t^{*}$, then:

$D A D_{\text {for organics }}=$

$\frac{F A \times K_{p} \times C_{w} \times\left[\frac{t_{\text {event }}}{(1+B)}+\left(2 \tau_{\text {event }} \times\left(\frac{1+3 B+3 B^{2}}{(1+B)^{2}}\right)\right)\right] \times E V \times E D \times E F \times S A}{A T \times 365(\text { days } / \text { year }) \times B W}$

Dermal Hazard Quotient $=D A D / R f D_{A B S}$

Where:

$D A D_{\text {for inorganics }}=\frac{C_{w} \times K_{p} \times t_{\text {event }} \times E V \times E D \times E F \times S A}{E D \times 365(\text { days } / \text { year }) \times B W}$

If $t_{\text {event }} \leq t^{*}$, then:

$D A D_{\text {for organics }}=\frac{2 \times F A \times K_{p} \times C_{w} \times \sqrt{\frac{6 \times \tau_{\text {event }} \times t_{\text {event }}}{\pi}} \times E V \times E D \times E F \times S A}{E D \times 365(\text { days } / \text { year }) \times B W}$

If $t_{\text {event }}>t^{*}$, then:

$D A D_{\text {for organics }}=$

$\frac{F A \times K_{p} \times C_{w} \times\left[\frac{t_{\text {event }}}{(1+B)}+\left(2 \tau_{\text {event }} \times\left(\frac{1+3 B+3 B^{2}}{(1+B)^{2}}\right)\right)\right] \times E V \times E D \times E F \times S A}{E D \times 365(\text { days } / \text { year }) \times B W}$

Exhibit B2b. Additional equations for estimating cancer risk and hazard quotient following dermal exposure to contaminants in residential drinking water [55].

Toxicity factors for dermal absorption:

$S F_{A B S}=S F_{0} / A B S_{G I}$

[55]

$R f D_{A B S}=R f D_{o} \times A B S_{G I}$

Lag time per event $\tau_{\text {event }}($ h/event):

$\tau_{\text {event }}=0.105 \times 10^{(0.0056 \times M W)}$

Where:

$\mathrm{MW}=$ Molecular Weight $(\mathrm{g} /$ mole $)$

(Chemical Specific)

Time to reach steady state $t^{*}(h)$ :

If $B<0.6$, then:

$t^{*}=2.4 \tau_{\text {event }}$

If $B>0.6$, then:

$t^{*}=\left(b-\sqrt{b^{2}-c^{2}}\right) \frac{I_{s c}{ }^{2}}{I_{s c} \times 10^{(-2.8-(0.0056 \times M W))}}$

Where:

$B=$ Ratio of the permeability coefficient of a compound through the stratum

corneum relative to its permeability coefficient across the viable epidermis (dimensionless)

$b, c=$ Correlation coefficients

$B=K_{p} \sqrt{M W / 2.6}$

$b=\frac{2(2+B)^{2}}{\pi}-c$

$c=\frac{1+3 B+3 B^{2}}{3(1+B)}$ 
Exhibit B2c. Sample calculation estimating cancer risk and hazard quotient following dermal exposure to flowback water with median concentration of Benzene (full hand exposure for $3 \mathrm{~h}$ ) [55].

$$
\begin{gathered}
\text { Median concentration of benzene in flowback water }=2.5 \times 10^{-3} \mathrm{mg} / \mathrm{L} \\
S F_{A B S}=S F_{o} / A B S_{G I}=5.5 \times 10^{-2} / 1=5.5 \times 10^{-2} \\
R f D_{A B S}=R f D_{o} \times A B S_{G I}=4.0 \times 10^{-3} \times 1=4.0 \times 10^{-3}
\end{gathered}
$$

Lag time per event $\tau_{\text {event }}$ (h/event):

$$
\tau_{\text {event }}=0.105 \times 10^{(0.0056 \times M W)}=2.87 \times 10^{-1}
$$

Time to reach steady state $t^{*}(h)$ :

If $B \leq 0.6$, then:

$$
\begin{gathered}
t^{*}=2.4 \tau_{\text {event }} \\
B=\text { Dimensionless ratio of permeability }=K_{p} \times \sqrt{M W / 2.6}=5.06 \times 10^{-2}<0.6 \\
\qquad \begin{array}{c}
t^{*}=2.4 \tau_{\text {event }}=2.4 \times 2.87 \times 10^{-1}=6.9 \times 10^{-1} \\
t_{\text {event }}=3 \mathrm{~h}>t^{*}
\end{array}
\end{gathered}
$$

For carcinogens: If $t_{\text {event }}>t^{*}$, then:

$$
\begin{gathered}
D A D_{\text {for organics }}=\frac{F A \times K_{p} \times C_{w} \times\left[\frac{t_{\text {event }}}{(1+B)}+\left(2 \tau_{\text {event }} \times\left(\frac{1+3 B+3 B^{2}}{(1+B)^{2}}\right)\right)\right] \times E V \times E D \times E F \times S A}{A T \times 365(\text { days } / \text { year }) \times B W} \\
\frac{1 \times 0.0149 \times 0.0025\left[\frac{3}{(1+0.0506)}+\left(2 \times 0.287 \times\left(\frac{1+3(0.0506)+3(0.0506)^{2}}{(1+(0.0506))^{2}}\right)\right)\right] \times 1 \times 4 \times 52 \times 491}{70 \times 365(\text { days } / \text { year }) \times 80}=6.44 \times 10^{-9} \\
\text { Dermal Cancer Risk }=D A D \times S F_{A B S}=6.44 \times 10^{-9} \times 5.5 \times 10^{-2}=3.5 \times 10^{-10}
\end{gathered}
$$

For non-carcinogens: If $t_{\text {event }}>t^{*}$, then:

$$
\begin{gathered}
D A D_{\text {for organics }}=\frac{F A \times K_{p} \times C_{w} \times\left[\frac{t_{\text {event }}}{(1+B)}+\left(2 \tau_{\text {event }} \times\left(\frac{1+3 B+3 B^{2}}{(1+B)^{2}}\right)\right)\right] \times E V \times E D \times E F \times S A}{E D \times 365(\text { days } / \text { year }) \times B W} \\
=\frac{1 \times 0.0149 \times 0.0025\left[\frac{3}{(1+0.0506)}+\left(2 \times 0.287 \times\left(\frac{1+3(0.0506)+3(0.0506)^{2}}{(1+(0.0506))^{2}}\right)\right)\right] \times 1 \times 4 \times 52 \times 491}{4 \times 365(\text { days } / \text { year }) \times 80}=1.13 \times 10^{-7} \\
\text { Dermal Hazard Quotient }=D A D / R f D_{A B S}=1.13 \times 10^{-7} / 4.0 \times 10^{-3}=2.8 \times 10^{-5}
\end{gathered}
$$

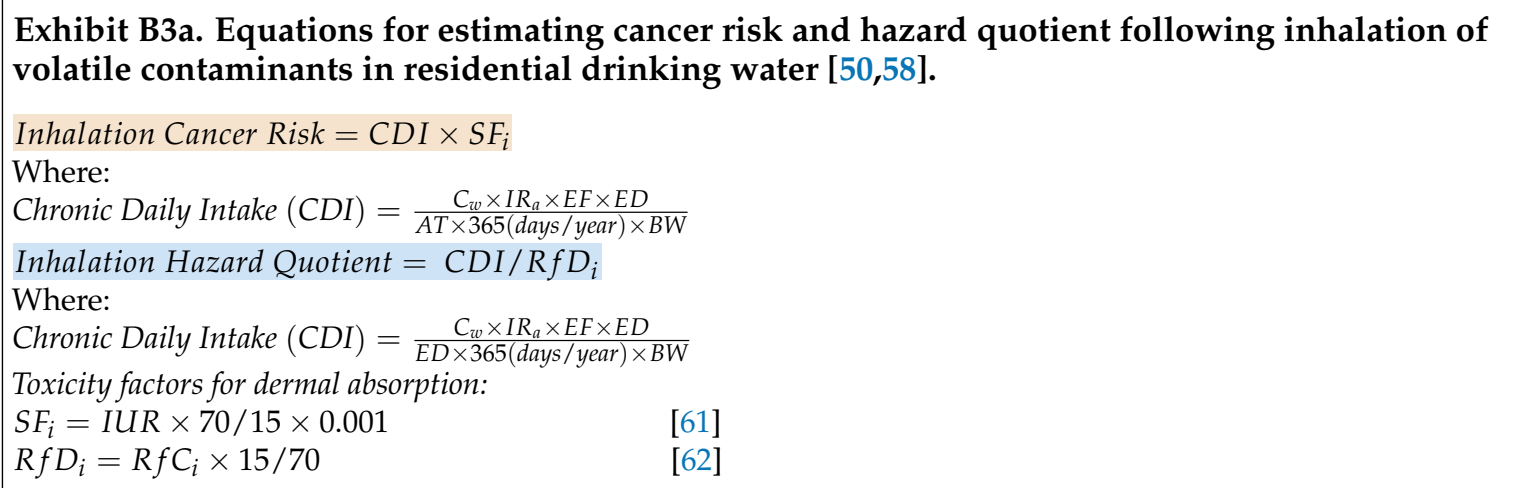


Exhibit B3b. Sample calculation estimating cancer risk and hazard quotient following
inhalation of median concentration of Benzene from residential drinking water [50,58].

Median concentration of benzene in drinking water $=3.75 \times 10^{-7} \mathrm{mg} / \mathrm{L}$

For carcinogenic effect:

Chronic Daily Intake $(C D I)=\frac{3.75 \times 10^{-7} \times 15 \times 350 \times 30}{70 \times 365 \times 80}=2.8 \times 10^{-8}$

Inhalation Cancer Risk $=C D I \times S F_{i}=2.8 \times 10^{-8} \times 3.64 \times 10^{-2}=1.05 \times 10^{-9}$

For non-carcinogenic effect:

Chronic Daily Intake $(C D I)=\frac{3.75 \times 10^{-7} \times 15 \times 350 \times 30}{30 \times 365 \times 80}=6.7 \times 10^{-8}$

Inhalation Hazard Quotient $=C D I / R f D_{i}=6.7 \times 10^{-8} / 6.43 \times 10^{-3}=1.05 \times 10^{-5}$

\section{Exhibit B4a. Equations for estimating cancer risk from exposure to radionuclides in} water [62-66].

Radionuclide Ingestion Cancer Risk $=C_{w} \times E F \times E D \times I R_{w} \times S F_{o}$

Radionuclide Immersion Cancer Risk $=C_{w} \times E F \times E D \times I R_{w} \times S F_{i m m}$

Radionuclide Inhalation Cancer Risk $=C_{w} \times E F \times E D \times I R_{a} \times S F_{i}$

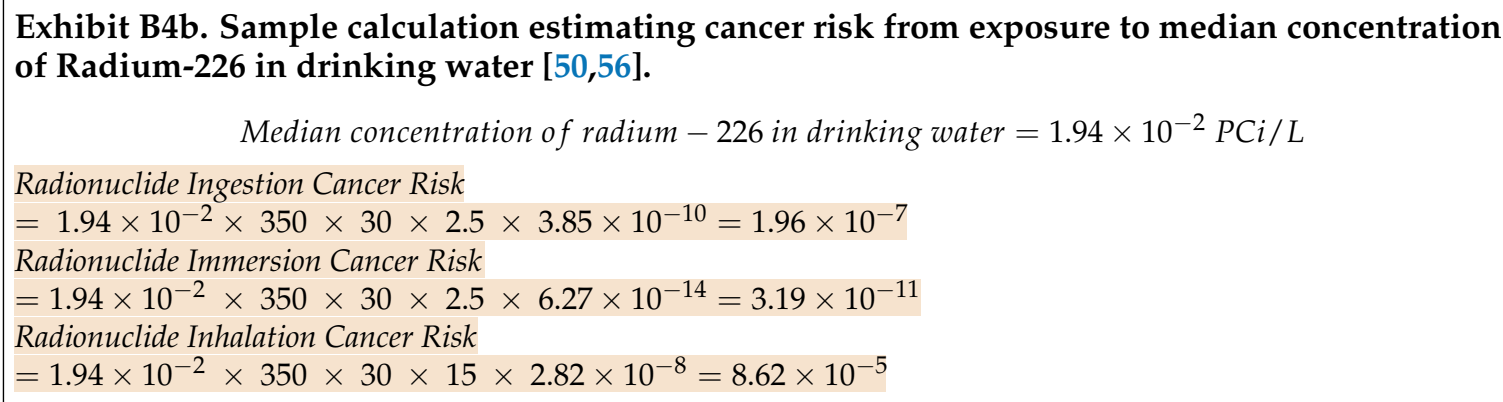

\section{References}

1. Colborn, T.; Schultz, K.; Herrick, L.; Kwiatkowski, C. An exploratory study of air quality near natural gas operations. Hum. Ecol. Risk Assess. Int. J. 2014, 20, 86-105. [CrossRef]

2. Stephenson, M.H. Shale gas in North America and Europe. Energy Sci. Eng. 2016, 4, 4-13. [CrossRef]

3. Clark, C.; Burnham, A.; Harto, C.; Horner, R. Hydraulic Fracturing and Shale Gas Production: Technology, Impacts, and Regulations; Argonne National Laboratory: Argonne, IL, USA, 2013.

4. NY State Department of Environmental Conservation. Final SGEIS on the Oil, Gas and Solution Mining Regulatory Program; Regulatory Program for Horizontal Drilling and High-Volume Hydraulic Fracturing to Develop the Marcellus Shale and Other Low-Permeability Gas Reservoirs; NY State Department of Environmental Conservation: New York, NY, USA, 2015.

5. Rozell, D.J.; Reaven, S.J. Water pollution risk associated with natural gas extraction from the Marcellus Shale. Risk Anal. 2012, 32, 1382-1393. [CrossRef] [PubMed]

6. Aminto, A.; Olson, M.S. Four-compartment partition model of hazardous components in hydraulic fracturing fluid additives. J. Nat. Gas Sci. Eng. 2012, 7, 16-21. [CrossRef]

7. US Environmental Protection Agency. Assessment of the Potential Impacts of Hydraulic Fracturing for Oil and Gas on Drinking Water Resources (External Review Draft); EPA/600/R-15/047; U.S. Environmental Protection Agency: Washington, DC, USA, 2015.

8. Schramm, E. What Is Flowback, and How Does It Differ from Produced Water; Institute for Energy and Environmental Research of Northeastern Pennsylvania Clearinghouse: University Park, PA, USA, 2011. 
9. Brantley, S.L.; Yoxtheimer, D.; Arjmand, S.; Grieve, P.; Vidic, R.; Pollak, J.; Llewellyn, G.T.; Abad, J.; Simon, C. Water resource impacts during unconventional shale gas development: The Pennsylvania experience. Int. J. Coal Geol. 2014, 126, 140-156. [CrossRef]

10. Small, M.J.; Stern, P.C.; Bomberg, E.; Christopherson, S.M.; Goldstein, B.D.; Israel, A.L.; Jackson, R.B.; Krupnick, A.; Mauter, M.S.; Nash, J.; et al. Risks and risk governance in unconventional shale gas development. Environ. Sci. Technol. 2014, 48, 8289-8297. [CrossRef] [PubMed]

11. Beaver, W. Environmental Concerns in the Marcellus Shale. Bus. Soc. Rev. 2014, 119, 125-146. [CrossRef]

12. Bloomdahl, R.; Abualfaraj, N.; Olson, M.; Gurian, P.L. Assessing worker exposure to inhaled volatile organic compounds from Marcellus Shale flowback pits. J. Nat. Gas Sci. Eng. 2014, 21, 348-356. [CrossRef]

13. Esswein, E.; Kiefer, S.M.J.; Breitenstein, M. NIOSH FIeld Effort to Assess Chemical Exposure Risks to Gas and Oil Workers; Department of Health and Human Services, Centers for Disease Control and Prevention, National Institute for Occupational Safety and Health: Washington, DC, USA, 2012.

14. McKenzie, L.M.; Witter, R.Z.; Newman, L.S.; Adgate, J.L. Human health risk assessment of air emissions from development of unconventional natural gas resources. Sci. Total Environ. 2012, 424, 79-87. [CrossRef] [PubMed]

15. Howarth, R.W.; Santoro, R.; Ingraffea, A. Methane and the greenhouse-gas footprint of natural gas from shale formations. Clim. Chang. 2011, 106, 679-690. [CrossRef]

16. Annevelink, M.P.J.A.; Meesters, J.A.J.; Hendriks, A.J. Environmental contamination due to shale gas development. Sci. Total Environ. 2016, 550, 431-438. [CrossRef] [PubMed]

17. Ferrar, K.J.; Michanowicz, D.R.; Christen, C.L.; Mulcahy, N.; Malone, S.L.; Sharma, R.K. Assessment of Effluent Contaminants from Three Facilities Discharging Marcellus Shale Wastewater to Surface Waters in Pennsylvania. Environ. Sci. Technol. 2013, 47, 3472-3481. [CrossRef] [PubMed]

18. Gordalla, B.C.; Ewers, U.; Frimmel, F.H. Hydraulic fracturing: A toxicological threat for groundwater and drinking-water? Environ. Earth Sci. 2013, 70, 3875-3893. [CrossRef]

19. Jackson, R.B.; Vengosh, A.; Darrah, T.H.; Warner, N.R.; Down, A.; Poreda, R.J.; Osborn, S.G.; Zhao, K.; Karr, J.D. Increased stray gas abundance in a subset of drinking water wells near Marcellus shale gas extraction. Proc. Natl. Acad. Sci. USA 2013, 110, 11250-11255. [CrossRef] [PubMed]

20. Lutz, B.D.; Lewis, A.N.; Doyle, M.W. Generation, transport, and disposal of wastewater associated with Marcellus shale gas development. Water Resour. Res. 2013, 49, 647-656. [CrossRef]

21. Osborn, S.G.; Vengosh, A.; Warner, N.R.; Jackson, R.B. Methane contamination of drinking water accompanying gas-well drilling and hydraulic fracturing. Proc. Natl. Acad. Sci. USA 2011, 108, 8172-8176. [CrossRef] [PubMed]

22. Soeder, D.J.; Kappel, W.M. Water Resources and Natural Gas Production from the Marcellus Shale; U.S. Geological Survey; U.S. Department of the Interior: Reston, VA, USA, 2009.

23. Vengosh, A.; Jackson, R.B.; Warner, N.; Darrah, T.H.; Kondash, A. A critical review of the risks to water resources from unconventional shale gas development and hydraulic fracturing in the United States. Environ. Sci. Technol. 2014, 48, 8334-8348. [CrossRef] [PubMed]

24. Vidic, R.D.; Brantley, S.L.; Vandenbossche, J.M.; Yoxtheimer, D.; Abad, J.D. Impact of Shale Gas Development on Regional Water Quality. Science 2013, 340, 1235009. [CrossRef] [PubMed]

25. Warner, N.R.; Christie, C.A.; Jackson, R.B.; Vengosh, A. Impacts of Shale Gas Wastewater Disposal on Water Quality in Western Pennsylvania. Environ. Sci. Technol. 2013, 47, 11849-11857. [CrossRef] [PubMed]

26. Zhang, X.; Sun, A.Y.; Duncan, I.J. Shale gas wastewater management under uncertainty. J. Environ. Manag. 2016, 165, 188-198. [CrossRef] [PubMed]

27. Energy Information Administration. Pennsylvania State Profile and Energy Estimates; U.S. Energy Information Administration: Washington, DC, USA, 2015.

28. Energy Information Administration. Monthly Crude Oil and Natural Gas Production; U.S. Energy Information Administration: Washington, DC, USA, 2017.

29. Heilweil, V.M.; Grieve, P.L.; Hynek, S.A.; Brantley, S.L.; Solomon, D.K.; Risser, D.W. Stream Measurements Locate Thermogenic Methane Fluxes in Groundwater Discharge in an Area of Shale-Gas Development. Environ. Sci. Technol. 2015, 49, 4057-4065. [CrossRef] [PubMed]

30. Siegel, D.I.; Azzolina, N.A.; Smith, B.J.; Perry, A.E.; Bothun, R.L. Methane Concentrations in Water Wells Unrelated to Proximity to Existing Oil and Gas Wells in Northeastern Pennsylvania. Environ. Sci. Technol. 2015, 49, 4106-4112. [CrossRef] [PubMed] 
31. Molofsky, L.J.; Connor, J.A.; Wylie, A.S.; Wagner, T.; Farhat, S.K. Evaluation of Methane Sources in Groundwater in Northeastern Pennsylvania. Groundwater 2013, 51, 333-349. [CrossRef] [PubMed]

32. Balaba, R.S.; Smart, R.B. Total Arsenic and Selenium Analysis in Marcellus Shale, High-Salinity Water and Hydrofracture Flowback Wastewater. Chemosphere 2012, 89, 1437-1442. [CrossRef] [PubMed]

33. Abualfaraj, N.; Gurian, P.L.; Olson, M.S. Characterization of Marcellus Shale Flowback Water. Environ. Eng. Sci. 2014, 31, 514-524. [CrossRef]

34. Blauch, M.E.; Myers, R.R.; Moore, T.; Lipinski, B.A.; Houston, N.A. Marcellush Shale Post-Frac Flowback Waters-Where is All the Salt Coming from and What are the Implications? In Proceedings of the SPE Eastern Regional Meeting, Society of Petroleum Engineers, Charleston, WV, USA, 23-25 September 2009.

35. Dresel, P.E.; Rose, A.W. Chemistry and Origin of Oil and Gas Well Brines in Western Pennsylvania; 4th Series; Pennsylvania Geological Survey: Pittsburgh, PA, USA, 2010.

36. Haluszczak, L.O.; Rose, A.W.; Kump, L.R. Geochemical evaluation of flowback brine from Marcellus gas wells in Pennsylvania, USA. Appl. Geochem. 2013, 28, 55-61. [CrossRef]

37. Hayes, T. Sampling and Analysis of Water Streams as- Sociated with the Development of Marcellus Shale Gas; Gas Technology Institute: Des Plaines, IL, USA, 2009.

38. Olmstead, S.M.; Muehlenbachs, L.A.; Shih, J.S.; Chu, Z.; Krupnick, A.J. Shale gas development impacts on surface water quality in Pennsylvania. Proc. Natl. Acad. Sci. USA 2013, 110, 4962-4967. [CrossRef] [PubMed]

39. US Environmental Protection Agency. Hydraulic Fracturing for Oil and Gas: Impacts from the Hydraulic Fracturing Water Cycle on Drinking Water Resources in the United States (Final Report); EPA/600/R-16/236F; Environmental Protection Agency: Washington, DC, USA, 2016.

40. Rahm, B.G.; Vedachalam, S.; Bertoia, L.R.; Mehta, D.; Vanka, V.S.; Riha, S.J. Shale gas operator violations in the Marcellus and what they tell us about water resource risks. Energy Policy 2015, 82, 1-11. [CrossRef]

41. Abualfaraj, N.; Olson, M.S.; Gurian, P.L.; De Roos, A.; Gross-Davis, C.A. Statistical Analysis of Compliance Violations for Natural Gas Wells in Pennsylvania. Energy Policy 2016, 97, 421-428. [CrossRef]

42. Ingraffea, A.R.; Wells, M.T.; Santoro, R.L.; Shonkoff, S.B. Assessment and risk analysis of casing and cement impairment in oil and gas wells in Pennsylvania, 2000-2012. Proc. Natl. Acad. Sci. USA 2014, 111, 10955-10960. [CrossRef] [PubMed]

43. Llewellyn, G.T.; Dorman, F.; Westland, J.L.; Yoxtheimer, D.; Grieve, P.; Sowers, T.; Humston-Fulmer, E.; Brantley, S.L.C. Evaluating a groundwater supply contamination incident attributed to Marcellus Shale gas development. Proc. Natl. Acad. Sci. USA 2015, 112, 6325-6330. [CrossRef] [PubMed]

44. Gross, S.A.; Avens, H.J.; Banducci, A.M.; Sahmel, J.; Panko, J.M.; Tvermoes, B.E. Analysis of BTEX groundwater concentrations from surface spills associated with hydraulic fracturing operations. J. Air Waste Manag. Assoc. 2013, 63, 424-432. [CrossRef] [PubMed]

45. Abualfaraj, N.; Gurian, P.L.; Olson, M.S. Frequency Analysis of Failure Scenarios from Shale Gas Development. 2018. in preparation.

46. Krupnick, A.; Gordon, H.; Olmstead, S.M. Pathways to Dialogue: What the Experts Say about the Environmental Risks of Shale Gas Development; Resources for the Future: Washington, DC, USA, 2013.

47. Galada, H.C.; Gurian, P.L.; Olson, M.S.; Teng, J.; Kumar, A.; Wardell, M.; Eggers, S.; Casman, E. Development of failure scenarios for biosolids land application risk assessment. Water Environ. Res. 2013, 85, 141-150. [CrossRef] [PubMed]

48. US Environmental Protection Agency. Guide to Septage Treatment and Disposal; EPA/625/R-94/002; U.S. Environmental Protection Agency: Washington, DC, USA, 1994.

49. US Environmental Protection Agency. Exposure Factors Handbook: 2011 Edition; U.S. Environmental Protection Agency: Washington, DC, USA, 2011.

50. US Environmental Protection Agency. Risk Assessment Guidance for Superfund Volume I: Human Health Evaluation Manual; OSRT. Innovation; U.S. Environmental Protection Agency: Washington, DC, USA, 2004.

51. USCG. National Response Center. 2016. Available online: http:/ / www.nrc.uscg.mil (accessed on 13 March 2016).

52. US Environmental Protection Agency. Risk Assessment Guidance for Superfund Volume I: Human Health Evaluation Manual (Part E, Supplemental Guidance for Dermal Risk Assessment); OSRT. Innovation; U.S. Environmental Protection Agency: Washington, DC, USA, 2004. 
53. US Environmental Protection Agency. Risk Assessment Guidance for Superfund Volume I: Human Health Evaluation Manual (Part B, Development of Risk-Based Preliminary Remidiation Goals); OSRT. Innovation; U.S. Environmental Protection Agency: Washington, DC, USA, 2004.

54. US Environmental Protection Agency. Limiting Values of Radionuclide Intake and Air Concentration and Dose Conversion Factors for Inhalation, Submersion, and Ingestion; Federal Guidance Report No. 11, OR. Programs; EPA-520/1-88-020; U.S. Environmental Protection Agency: Washington, DC, USA, 1988.

55. US Environmental Protection Agency. Risk Assessment Guidance for Superfund Volume I: Human Health Evaluation Manual (Part F, Supplemetal Guidance for Inhalation Risk Assessment); OSRT. Innovation; U.S. Environmental Protection Agency: Washington, DC, USA, 2004.

56. Durant, B.; Abualfaraj, N.; Olson, M.S.; Gurian, P.L. Assessing dermal exposure risk to workers from flowback water during shale gas hydraulic fracturing activity. J. Nat. Gas Sci. Eng. 2016, 34, 969-978. [CrossRef]

57. U.S. Environmental Protection Agency. Integrated Risk Inormation System (IRIS). 2016. Available online: www.epa.gov/IRIS (accessed on 12 June 2016).

58. ATSDR, Agency for Toxic Substances and Disease Registry. Health Effects of Exposure to Substances and Carcinogens; ATSDR: Atlanta, GA, USA, 2011.

59. National Institute for Occupational Safety and Health (NIOSH). Pocket Guide to Chemical Hazards; NIOSH: Atlanta, GA, USA, 2007.

60. U.S. Environmental Protection Agency. OSWER Directive 9200.1-120; U.S. Environmental Protection Agency: Washington, DC, USA, 2014.

61. CALEPA. The California Environmental Protection Agency (OEHHA) Office of Environmental Health Hazard Assessment; CALEPA: Sacramento, CA, USA, 2008.

62. Health Effects Assessment Summary Tables for Superfund (HEAST). EPA Superfund and Resource Conservation and Recovery Act (RCRA) Hazardous Waste Programs; HEAST: Washington, DC, USA, 2011.

63. PPRTV. Provisional Peer Reviewed Toxicity Values for Superfund for Aluminum; Office of Superfund Remediation and Technology Innovation: Washington, DC, USA, 2006.

64. PPRTV. Provisional Peer Reviewed Toxicity Values for Superfund for Iron; Office of Superfund Remediation and Technology Innovation: Washington, DC, USA, 2006.

65. PPRTV. Provisional Peer Reviewed Toxicity Values for Superfund for 1,2-Dichloroethane; Office of Superfund Remediation and Technology Innovation: Washington, DC, USA, 2011.

66. PPRTV. Provisional Peer Reviewed Toxicity Values for Superfund for Thallium; Office of Superfund Remediation and Technology Innovation: Washington, DC, USA, 2012. 